\title{
Changes in soil physicochemical properties and bacterial communities at different soil depths after long-term straw mulching under a no-till system
}

\author{
Zijun Zhou ${ }^{1,4, \star}$, Zengqiang Li $^{2, \star}$, Kun Chen ${ }^{1,4}$, Zhaoming Chen ${ }^{3}$, Xiangzhong Zeng ${ }^{1,4}$, Hua Yu ${ }^{1,4}$, \\ Song Guo ${ }^{1,4}$, Yuxian Shangguan ${ }^{1,4}$, Qingrui Chen ${ }^{1,4}$, Hongzhu Fan ${ }^{1,4}$, Shihua Tu ${ }^{1,4}$, Mingjiang He ${ }^{1,4}$, \\ and Yusheng Qin ${ }^{1,4}$ \\ ${ }^{1}$ Institute of Agricultural Resources and Environment, \\ Sichuan Academy of Agricultural Sciences, Chengdu, China \\ ${ }^{2}$ College of Resources and Environment, Qingdao Agricultural University, Qingdao, China \\ ${ }^{3}$ Institute of Environmental Resources and Soil Fertilizer, \\ Zhejiang Academy of Agricultural Sciences, Hangzhou, China \\ ${ }^{4}$ Monitoring and Experimental Station of Plant Nutrition and Agro-Environment for \\ Sloping Land in South Region, Ministry of Agriculture and Rural Affairs, Chengdu, China \\ « These authors contributed equally to this work.
}

Correspondence: Yusheng Qin (shengyuq@ 126.com) and Qingrui Chen (qingruichen@ 163.com)

Received: 9 March 2021 - Discussion started: 19 April 2021

Revised: 30 July 2021 - Accepted: 11 August 2021 - Published: 8 September 2021

\begin{abstract}
Conservation tillage has attracted increasing attention over recent decades, mainly due to its benefits for improving soil organic matter content and reducing soil erosion. However, the effects of long-term straw mulching under a no-till system on soil physicochemical properties and bacterial communities at different soil depths are still unclear. In this 12-year experiment of straw removal (CK) and straw mulching (SM) treatments, soil samples were collected at $0-5,5-10,10-20$, and $20-30 \mathrm{~cm}$ soil depths. The results showed that the contents of organic carbon $(\mathrm{C})$, nitrogen $(\mathrm{N})$, and phosphorus $(\mathrm{P})$ fractions, and bacterial abundance significantly decreased, whereas pH significantly increased with soil depth. Compared with CK, SM significantly increased total $\mathrm{N}$, inorganic $\mathrm{N}$, available $\mathrm{P}$, available potassium, and soil water content at $0-5 \mathrm{~cm}$, total organic $\mathrm{C}$ content at $0-10 \mathrm{~cm}$, and dissolved organic $\mathrm{C}$ and $\mathrm{N}$ contents at $0-20 \mathrm{~cm}$. Regarding bacterial communities, $\mathrm{SM}$ increased the relative abundances of Proteobacteria, Bacteroidetes, and Acidobacteria but reduced those of Actinobacteria, Chloroflexi, and Cyanobacteria. Bacterial Shannon diversity and Shannon's evenness at $0-5 \mathrm{~cm}$ were reduced by SM treatment compared to CK treatment. Furthermore, SM increased the relative abundances of some C-cycling genera (such as Terracidiphilus and Acidibacter) and N-cycling genera (such as Rhodanobacter, Rhizomicrobium, Dokdonella, Reyranella, and Luteimonas) at $0-5 \mathrm{~cm}$. Principal coordinate analysis showed that the largest difference in the composition of soil bacterial communities between CK and SM occurred at $0-5 \mathrm{~cm}$. Soil pH and $\mathrm{N}$ and organic $\mathrm{C}$ fractions were the major drivers shaping soil bacterial communities. Overall, $\mathrm{SM}$ treatment is highly recommended under a no-till system because of its benefits to soil fertility and bacterial abundance.
\end{abstract}




\section{Introduction}

The global demand for food depends largely on agricultural production to feed growing populations (Karthikeyan et al., 2020). Conventional intensive agriculture puts unprecedented stress on soils and results in their degradation through soil organic matter loss, erosion, and genetic diversity loss (Hou et al., 2020; Kopittke et al., 2019; Lupwayi et al., 2012). In contrast, conservation agriculture centered on conservation tillage has been widely recommended for sustaining and improving agriculture production in recent decades because it can increase soil organic matter content, improve soil structure, reduce soil erosion, and decrease the need for farm labor (Jena, 2019; Singh et al., 2020). In 2013, the global conservation tillage area was approximately $155 \mathrm{Mha}$, corresponding to approximately $11 \%$ of crop land worldwide (Kassam et al., 2014). Generally, conservation tillage practices follow two key principles: minimal soil disturbance (no or reduced tillage) and soil cover (mainly straw mulch) (Pittelkow et al., 2015). Researchers have assessed the differences between conventional tillage and conservation tillage in terms of crop yield and soil properties (Bu et al., 2020; Gao et al., 2021; Hao et al., 2019; Hu et al., 2021). However, straw mulching is not always combined with no-till practices in many countries due to poor productivity, the prioritization of livestock feeding, or insufficient time available for applying straw mulch (Giller et al., 2009; Jin, 2007; Pittelkow et al., 2015; Zhao et al., 2018). Therefore, the separation of straw mulching effects could refine our understanding of the function of straw in soil properties as the area of conservation tillage in the world increases.

Soil physicochemical properties are important contributors to soil fertility, which is a critical factor determining crop productivity and agricultural sustainability (Liu et al., 2019). Because straw contains large amounts of carbon (C), nitrogen $(\mathrm{N})$, phosphorus $(\mathrm{P})$, and potassium $(\mathrm{K})$, straw mulching is reported to increase the soil's total organic C, its fractions, soil enzymes (invertase, phosphatase, urease, and catalase), and other physicochemical properties (Akhtar et al., 2018; Dai et al., 2019; Duval et al., 2016; L. Wang et al., 2019; Zhou et al., 2019a, b). Many studies have focused on changes in these properties in topsoil, as topsoil provides large amounts of nutrients to plants (Dai et al., 2019; L. Wang et al., 2019; Zhou et al., 2019a). However, soil physicochemical properties in the subsoil should also be considered, as some nutrients may move from topsoil to deeper soil depths during irrigation and rainfall (Blanco-Canqui and Lal, 2007; Stowe et al., 2010). Inconsistent results from the distribution of physicochemical properties along soil depths have been reported in cultivated agricultural soils or grasslands ( $\mathrm{Li}$ et al., 2017; Peng and Wang, 2016). Variations in physicochemical properties among different soil depths after long-term straw mulching under a no-till system are still unclear, as no-till practices cause few disturbances to the soil and are quite different from the heavy tillage practiced in conventional agriculture.

Soil bacterial communities have been used as sensitive indicators of soil quality in agricultural systems (Ashworth et al., 2017) and play a vital role in soil ecological processes such as soil carbon, nutrient cycling, and greenhouse gas release (Hobara et al., 2014; Tellez-Rio et al., 2015; Thompson et al., 2017). Reports of the responses of soil bacterial abundance and communities to straw mulching in the topsoil have been inconsistent (Bu et al., 2020; Chen et al., 2017; Hao et al., 2019; Qiu et al., 2020). Chen et al. (2017) proposed that straw return significantly increased bacterial biomass in one region but had no significant effect in other regions. Regarding bacterial phyla, the relative abundance of Actinobacteria was enriched in straw mulch soils in the Loess Plateau of China (Qiu et al., 2020) but was reduced under a wheatmaize rotation system (Hao et al., 2019). Moreover, soil microorganisms in deep soil layers have attracted the attention of researchers because they have important effects on soil formation, ecosystem biochemistry processes, and maintaining groundwater quality (Li et al., 2014). Several studies have shown that bacterial abundances and community composition change with soil depth (Fierer et al., 2003; van Leeuwen et al., 2017). Unfortunately, no detailed information has been obtained about the soil bacterial community changes that occur in response to straw mulching at different soil depths under no-till systems.

Rice-wheat rotation is a major cropping system in China, and approximately 80 million tons of crop straw are produced annually in southwestern China (Li et al., 2016; Zhou et al., 2019b). This area has a humid, midsubtropical monsoon climate with an average annual precipitation of $1200 \mathrm{~mm}$. The abundant precipitation could promote the leaching of water-soluble organic matter and nutrients derived from straw deep into the soil, which may result in significant differences in soil properties at deeper depths. Although we assessed some soil organic $\mathrm{C}$ fractions under a no-till system in our previous study (Zhou et al., 2019b), little is known about how other soil physicochemical parameters vary with soil depth. We hypothesized that (1) compared with straw removal, straw mulching would significantly change soil properties, which would decline with increasing soil depth; and (2) the key soil physicochemical properties shaping bacterial communities would be different at different depths. In this study, a field was subjected to two straw management programs under a 12 year no-till system in the Chengdu Plain to (1) determine the effects of straw mulching on soil physicochemical parameters, bacterial abundance, and community composition at different depths, and (2) clarify the differences in the key soil physicochemical properties shaping bacterial communities at increasing soil depths. 


\section{Materials and methods}

\subsection{Experimental site and design}

A long-term field experiment was begun in 2005 in Guanghan, Sichuan Province, China $\left(31^{\circ} 08^{\prime} 38^{\prime \prime} \mathrm{N}, 104^{\circ} 29^{\prime} 45^{\prime \prime} \mathrm{E}\right)$. Before the experiment, the local agricultural soil was seldom tilled due to a shortage of tillage machines. The soil had been managed for a long period of time under the same agricultural cropping system, and consequently the fertility heterogeneity of the soil was considered minimal. The soil is a fluvo-aquic soil with loamy clay. The soil pH in 2005 was 5.54 , and the total organic $\mathrm{C}$, total $\mathrm{N}$, available $\mathrm{N}$, available $\mathrm{P}$, and available $\mathrm{K}$ levels were $18.1 \mathrm{~g} \mathrm{~kg}^{-1}, 2.03 \mathrm{~g} \mathrm{~kg}^{-1}$, $189.76 \mathrm{mg} \mathrm{kg}^{-1}, 12.61 \mathrm{mg} \mathrm{kg}^{-1}$, and $258.2 \mathrm{mg} \mathrm{kg}^{-1}$, respectively.

The experiment included two treatments with three replicates and used a randomized design. Each plot measured $12 \mathrm{~m}^{2}(3 \times 4 \mathrm{~m})$. Two treatments, i.e., a control (CK, straw removal) and straw mulching (SM), were applied using a notill rice-wheat rotation system. The straw was removed in the CK treatment, whereas rice and wheat straw were distributed over the soil surface without being chopped after harvest each year in the SM treatment. The mulch consisted of approximately $8.5 \mathrm{tha}^{-1}$ rice straw and $6.0 \mathrm{tha}^{-1}$ wheat straw each year. During the experiment, equal amounts of inorganic fertilizer were added in both treatments by manual broadcast over the soil surface without tillage. The doses of $\mathrm{N}, \mathrm{P}_{2} \mathrm{O}_{5}$, and $\mathrm{K}_{2} \mathrm{O}$ fertilizers were at 180,90 , and $90 \mathrm{~kg} \mathrm{ha}^{-1}$, respectively, in the wheat season and 165,60 , and $90 \mathrm{~kg} \mathrm{ha}^{-1}$, respectively, in the rice season. Nitrogen as urea was applied as fertilizer in the sowing and tillering stages at rates of $30 \%$ and $70 \%$, respectively, during the wheat season and $70 \%$ and $30 \%$, respectively, during the rice season. Potassium as potassium chloride was applied as fertilizer in the sowing and tillering stages at rates of $50 \%$ each during both the wheat and rice seasons. Phosphorus as calcium superphosphate was applied as fertilizer once at sowing during both the wheat and rice growing seasons. Other detailed information about the experimental design is provided in our previous study (Zhou et al., 2019b).

\subsection{Soil sampling}

Immediately after the wheat harvest in 2018 , soil columns of $0-30 \mathrm{~cm}$ were collected from five points in each plot using a stainless steel auger ( $40 \mathrm{~mm}$ interior diameter). Each soil column was divided into four samples from soil depths of $0-5,5-10,10-20$, and $20-30 \mathrm{~cm}$. Samples from the same soil depth at five different sampling points were pooled to make one composite sample for each depth of $0-5,5-10,10$ 20 , and $20-30 \mathrm{~cm}$ for each plot. The mixed soil was passed through a $2 \mathrm{~mm}$ mesh and divided into three parts: one was air-dried and used to measure soil $\mathrm{pH}$, total organic $\mathrm{C}$, total $\mathrm{N}$, total $\mathrm{P}$, total $\mathrm{K}$, available $\mathrm{P}$, and available $\mathrm{K}$; one was kept at $4{ }^{\circ} \mathrm{C}$ ( $<1$ week) for soil $\mathrm{NH}_{4}^{+}-\mathrm{N}, \mathrm{NO}_{3}^{-}-\mathrm{N}$, dissolved organic $\mathrm{C}$ (DOC), and dissolved organic $\mathrm{N}$ (DON) analysis; and the third was stored at $-80^{\circ} \mathrm{C}$ for soil bacterial community analysis.

\subsection{Soil physicochemical properties}

DOC and DON were extracted from the soil by shaking fresh soil samples with distilled water $(1: 5$ soil : solution ratio), and the extracts were then filtered for analysis using a Multi N/C 3100 analyzer (Analytik Jena AG, Jena, Germany) (Zhou et al., 2019b). Soil water content was determined using the gravimetric method after drying the soil to a constant weight at $105^{\circ} \mathrm{C}$ (Akhtar et al., 2018). Soil inorganic $\mathrm{N}, \mathrm{pH}$, total organic $\mathrm{C}$, total $\mathrm{N}$, total $\mathrm{P}$, total $\mathrm{K}$, available $\mathrm{P}$, and available $\mathrm{K}$ were determined as described by $\mathrm{Lu}$ (2000). Briefly, concentrations of $\mathrm{NH}_{4}^{+}-\mathrm{N}$ and $\mathrm{NO}_{3}^{-}-\mathrm{N}$ in filtered $2 \mathrm{M} \mathrm{KCl}$ extracts from fresh soil were measured using a continuous-flow auto-analyzer (AA3, Seal Analytical Inc., Southampton, UK). Inorganic $\mathrm{N}$ concentrations were calculated as the sum of $\mathrm{NH}_{4}^{+}-\mathrm{N}$ and $\mathrm{NO}_{3}^{-}-\mathrm{N}$. Soil $\mathrm{pH}$ was determined in a $1: 2.5$ soil: water aqueous suspension using an Orion 3-star benchtop pH meter (Thermo Scientific, Waltham, MA, USA). The soil's total organic C was determined using the dichromate oxidation and ferrous sulfate titration method, and the soil's total $\mathrm{N}$ was determined using the continuous-flow auto-analyzer after digestion based on the Kjeldahl method. For measurements of the soil's total $\mathrm{P}$ and total $\mathrm{K}$, soils were first digested using a mixed acid solution of $\mathrm{H}_{2} \mathrm{SO}_{4}$ and $\mathrm{HClO}_{4}$; total $\mathrm{P}$ was then analyzed using the continuous-flow auto-analyzer, and total $\mathrm{K}$ was determined by atomic absorption photometry. The soil's available $\mathrm{P}$ was extracted using $0.025 \mathrm{M} \mathrm{HCl}-0.03 \mathrm{M} \mathrm{NH}_{4} \mathrm{~F}$ and measured by ammonium molybdate colorimetry, and available $\mathrm{K}$ was extracted using $2 \mathrm{MHNO}_{3}$ and measured by atomic absorption photometry. Results of the soil's total organic C and DOC were reported in our previous study (Zhou et al., 2019b).

\subsection{DNA extraction and QPCR amplification}

DNA was extracted from $0.5 \mathrm{~g}$ of fresh soil using the Fast $^{\circledR}$ DNA SPIN Kit (MP Biomedicals, Santa Ana, CA, USA) according to the manufacturer's instructions (Zhou et al., 2017). The extracted DNA was dissolved in $50 \mu \mathrm{L}$ of double-distilled water, and its quality and concentration were checked using a NanoDrop 2000 spectrophotometer (CallejaCervantes et al., 2015). The DNA samples were then stored at $-80^{\circ} \mathrm{C}$ until further use. qPCR was used to quantify bacterial abundances based on the 16S rRNA gene using the primers 338F (5-ACTCCT ACGGGAGGCAGCAG-3) and 518R (5-ATTACCGCGGCTGCTGG-3) (Fierer et al., 2005). The qPCR procedure was carried out according to Chen et al. (2019) with some modifications. PCR was performed using a Bio-Rad CFX 96-well Thermocycler (Bio-Rad, Her- 
cules, CA, USA). The reactions were performed in a $20 \mu \mathrm{L}$ mixture containing $16.5 \mu \mathrm{L} 2 \times$ SYBR Color qPCR Master Mix, $0.5 \mu \mathrm{M}(0.8 \mu \mathrm{L})$ each primer, and $2 \mu \mathrm{L}$ DNA template. The PCR conditions were as follows: $95^{\circ} \mathrm{C}$ for $5 \mathrm{~min}$; $40 \mathrm{cy}$ cles of $30 \mathrm{~s}$ at $95^{\circ} \mathrm{C}, 30 \mathrm{~s}$ at $58^{\circ} \mathrm{C}$, and $40 \mathrm{~s}$ at $72^{\circ} \mathrm{C}$; and finally, $10 \mathrm{~min}$ at $72^{\circ} \mathrm{C}$. All samples were evaluated in triplicate. Standard curves were obtained using 10 -fold serial dilutions of linearized recombinant plasmids containing cloned 16S rDNA with known copy numbers. Melting curve analysis was performed at the end of each qPCR run to check the specificity of PCR products. PCR amplification efficiencies were between $96 \%$ and $105 \%$, with $R^{2}$ values $>0.99$.

\subsection{S rRNA amplification for Illumina sequencing and data processing}

The primers 515F (5-GTGCCAGCMGCCGCGG-3) and 907R (5-CCGTCAATTCMTTTRAGTTT-3) were used to amplify the V4-V5 regions of bacterial DNA (Caporaso et al., 2012). Detailed operational information can be found in Zhang et al. (2019). The $16 \mathrm{~S}$ rRNA sequences were analyzed on the I-Sanger Cloud Platform (https://cloud.majorbio. com/, last access: 12 July 2021). Raw sequences were merged using FLASH version 1.2.7 (Magoc and Salzberg, 2011) and processed using Quantitative Insights Into Microbial Ecology (QIIME v.1.9.0; http://www.qiime.org/, last access: 10 December 2020) (Quast et al., 2013). Poor-quality sequences (average quality score $<25$ ) and short sequences $(<200 \mathrm{bp})$ were removed. Primers were matched exactly, allowing two mismatched nucleotides, and reads with ambiguous bases were removed. Sequences with overlaps longer than $10 \mathrm{bp}$ were merged according to their overlap sequence. After this step, 945665 clean reads were obtained, with 30241 to 58191 reads per sample. Operational taxonomic units (OTUs) were clustered at a similarity threshold of $97 \%$ using the ribosomal database project (RDP) classifier with the Bayesian algorithm. The number of sequences per soil sample was rarefied to an equal abundance as the sample with the lowest number of sequences (Menéndez-Serra et al., 2019; Ye et al., 2017), and 4101 OTUs were identified across all samples. The taxonomy of each 16S rRNA gene sequence was analyzed using RDP Classifier against the SILVA database version 132 with a confidence threshold of $70 \%$ (Quast et al., 2013). Good's coverage was used to investigate the sequence coverage of the bacterial communities. The $\alpha$-diversity parameters, including the Shannon index, Shannon's evenness, and Chao1, were estimated using the Mothur program (http://www.mothur.org, last access: 12 July 2021). The Shannon index and Shannon's evenness were used to investigate soil bacterial community diversity and evenness, respectively. Chaol was used to describe soil bacterial community richness.

\subsection{Statistical analysis}

The homogeneity of variance and normality were assessed using Levene and Shapiro-Wilk tests before analysis of variance (ANOVA). Data normalization was achieved by transforming the soil's available $\mathrm{P}$ content by $\log (x)$ and relative abundances of Acidobacteria and Planctomycetes by $1 /(x)^{0.5}$. Two-way ANOVA was used to determine the main effects of soil depth and straw management strategy and their interactions on soil physicochemical parameters, bacterial abundance, bacterial $\alpha$-diversity indices, and relative abundances of bacterial phyla. Welch's $t$-tests within STAMP (Parks et al., 2014) were used to identify genera with significant differences in relative abundance between CK and SM at each depth. Pearson's correlation analysis was used to assess the relationships between bacterial communities and soil physicochemical parameters. These statistical analyses were performed using SPSS 19.0 (SPSS, Inc., Chicago, IL, USA). Principal coordinate analysis (PCoA) was then used to demonstrate patterns of similarity in bacterial community structures between CK and SM based on weighted UniFrac distances. Environmental factors were selected using Monte Carlo permutations (calculated based on 999), and environmental factors with $P>0.05$ were removed from a redundancy analysis (RDA) (Fan and Xing, 2016). Analysis of similarity (Adonis) analysis was performed based on OTU data using the vegan package of the $\mathrm{R}$ project (http://www.r-project.org, last access: 12 July 2021). The Monte Carlo Mantel test and RDA were performed using Canoco 5.0 (CANOCO, Microcomputer Power Inc., Ithaca, NY, USA) to identify the soil environmental factors that were significantly correlated with soil bacterial communities. PCoA plots were drawn using the I-Sanger Cloud Platform (https://cloud.majorbio.com/, last access: 12 July 2021), and other graphs were prepared using SigmaPlot ver. 12.5 (Systat, Software, Inc., San Jose, CA, USA).

\section{Results}

\subsection{Soil physicochemical properties}

Data shown are expressed as means \pm standard deviations of three replicates. Two-way ANOVA showed that straw management, soil depth, and their interaction had significant effects on the soil's total organic $\mathrm{C}$, total $\mathrm{N}$, inorganic $\mathrm{N}$, available $\mathrm{P}$, available K, DOC, and DON, and both the main effects of straw management and soil depth had significant effects on soil water content (Table 1). All soil physicochemical parameters, except total $\mathrm{K}$, were changed significantly with soil depth. Specifically, soil $\mathrm{pH}$ values were lowest at $0-5 \mathrm{~cm}$ and increased with soil depth; total $\mathrm{K}$ was unchanged among the four depths, and other physicochemical properties decreased with soil depth (Table 1). The soil's total organic $\mathrm{C}$, total $\mathrm{N}$, inorganic $\mathrm{N}$, available $\mathrm{P}$, available $\mathrm{K}$, DOC, $\mathrm{DON}$, and water content were generally significantly higher 
under SM treatment than CK treatment (Table 1), especially the soil's total organic $\mathrm{C}$ at $0-5$ and $5-10 \mathrm{~cm}$, the soil's total $\mathrm{N}$, inorganic $\mathrm{N}$, available $\mathrm{P}$, available $\mathrm{K}$, and water content at $0-5 \mathrm{~cm}$, soil DOC at $0-5,5-10$, and $10-20 \mathrm{~cm}$, and soil DON at $0-5$ and $10-20 \mathrm{~cm}$ (Table 2).

\subsection{Bacterial abundance}

Straw management, soil depth, and their interaction significantly affected soil bacterial abundance as measured by the 16S rRNA gene copy number (Table 3). Soil bacterial abundance declined significantly as soil depth increased in both treatment groups $(P<0.0001)$, and bacterial abundance under SM treatment was $52.69 \%$ higher than that under CK treatment $(P<0.05)$. Compared with $\mathrm{CK}$ treatment, SM treatment significantly increased bacterial abundance at 0 $5 \mathrm{~cm}(P<0.05)$, but there was no significant difference between the two treatments at the other three depths (Table 4).

\subsection{Bacterial $\alpha$-diversity}

The Good's coverage value for all samples was greater than $96 \%$ in our study, which indicated that the number of sequence reads adequately represented the bacteria. Table 3 shows that soil depth had a significant effect on three $\alpha$ diversity indices (Shannon diversity, Shannon's evenness, and Chao1) $(P<0.05)$. Shannon diversity was higher at 0 $20 \mathrm{~cm}$ than at $20-30 \mathrm{~cm}$, whereas Shannon's evenness was highest at $0-5 \mathrm{~cm}$ with the lowest value at $20-30 \mathrm{~cm}$. Chao 1 first increased, reaching the highest value at $5-10 \mathrm{~cm}$, then decreased with soil depth (Table 4). Compared to CK treatment, SM treatment reduced Shannon diversity and Shannon's evenness at $0-5 \mathrm{~cm}$, but there was no difference at the other three depths. Chao1 did not differ between CK and SM at any depth.

\subsection{Bacterial community composition}

Phyla whose relative abundances accounted for less than $1 \%$ of all soil samples were merged into the "Others" category. As a result, 14 phyla were identified in the study. From highest to lowest relative abundance these were Proteobacteria, Acidobacteria, Chloroflexi, Actinobacteria, Planctomycetes, Nitrospirae, Others, Gemmatimonadetes, Unclassified, Firmicutes, Bacteroidetes, Latescibacteria, Verrucomicrobia, and Cyanobacteria (Fig. S1 in the Supplement). Twoway ANOVA showed that soil depth significantly altered the relative abundances of almost all phyla, except Firmicutes and Verrucomicrobia (Table 3). Specifically, the relative abundances of Proteobacteria, Actinobacteria, Bacteroidetes, and Cyanobacteria decreased, whereas those of Chloroflexi, Nitrospirae, and Latescibacteria increased as soil depth increased $(P<0.05)$ under both treatments. The relative abundance of Acidobacteria increased from $0-5$ to $10-20 \mathrm{~cm}$, then decreased at $20-30 \mathrm{~cm}$. The relative abundance of Plancto- mycetes did not change among the $0-5,5-10$, and $10-20 \mathrm{~cm}$ depths but significantly decreased at $20-30 \mathrm{~cm}$. The relative abundance of Gemmatimonadetes first increased and then decreased with soil depth, and its highest abundance was at $5-10 \mathrm{~cm}$. Meanwhile, two-way ANOVA showed that compared to CK treatment, SM treatment significantly increased the relative abundances of Proteobacteria, Acidobacteria, Bacteroidetes, and Latescibacteria, but decreased those of Actinobacteria, Chloroflexi, and Cyanobacteria (Tables 3 and 4). Table 4 shows that SM treatment significantly increased relative abundances of Proteobacteria at $0-5 \mathrm{~cm}$, Acidobacteria at 10-20 and 20-30 cm, and Bacteroidetes at $0-5$ and $10-20 \mathrm{~cm}$ compared with CK treatment, whereas SM treatment significantly reduced the relative abundances of Actinobacteria at $10-20 \mathrm{~cm}$, Chloroflexi at $0-5$ and $10-20 \mathrm{~cm}$, and Cyanobacteria at $0-5$ and $20-30 \mathrm{~cm}$ compared with CK treatment $(P<0.05)$.

After taxonomic assignment, 297, 290, 286, and 288 classified genera were obtained from the $0-5,5-10,10-20$, and $20-30 \mathrm{~cm}$ soil layers, respectively, across the two treatments. In this study, we focused on the genera that accounted for more than $0.25 \%$ of the relative abundance of the bacterial community in any soil sample (Fig. 1). Compared to CK treatment, SM treatment increased the relative abundances of the genera Rhodanobacter, Rhizomicrobium, Dokdonella, Pseudolabrys, Acidibacter, Devosia, Reyranella, Luteimonas, and Porphyrobacter in the phylum Proteobacteria and the genus Terracidiphilus in the phylum Acidobacteria but decreased those of the genera Anaeromyxobacter and Syntrophobacter in the phylum Proteobacteria, the genera Mycobacterium and Streptomyces in the phylum Actinobacteria, and the genera Gemmata and Isosphaera in the phylum Planctomycetes at $0-5 \mathrm{~cm}(P<0.05)$. There were no significantly different genera with an abundance greater than $0.25 \%$ between CK and SM at $5-10 \mathrm{~cm}(P>0.05)$. At $10-20 \mathrm{~cm}$, the relative abundances of the genus $R B 41$ in the phylum Acidobacteria, the genus Flavobacterium in the phylum Bacteroidetes, and the genus Lysobacter in the phylum Proteobacteria were increased, whereas those of the genus Desulfobacca in the phylum Proteobacteria and the genera Luedemannella, Mycobacterium, and Streptomyces in the phylum Actinobacteria were decreased under SM treatment $(P<0.05)$. Compared to $\mathrm{CK}$ treatment, SM treatment significantly increased the relative abundance of Flavobacterium at $20-30 \mathrm{~cm}(P<0.05)$.

\subsection{Bacterial community structure}

PCoA showed differences among bacterial community structures in the 24 samples (Fig. 2). The first two principal coordinates, PC1 and PC2, accounted for $65.48 \%$ and $11.26 \%$ of the total variation, respectively. The PC1 coordinate separated the soil samples into four groups along the soil depth gradient, regardless of straw treatment. Furthermore, the largest difference in the composition of soil bacterial com- 
Table 1. Two-way ANOVA analysis of soil physicochemical properties at four depths under two straw management strategies, each with three replicates. The data in bold indicate soil physicochemical properties that were not affected by straw management, soil depth, or their interaction $(P>0.05)$. DOC, dissolved organic carbon; DON, dissolved organic nitrogen.

\begin{tabular}{lrr|rr|rr}
\hline Physicochemical & \multicolumn{2}{c|}{ Straw } & \multicolumn{2}{|c|}{ Depth } & \multicolumn{2}{|c}{ Straw $\times$ Depth } \\
\cline { 2 - 7 } properties & $F$ & $P$ & $F$ & $P$ & $F$ & $P$ \\
\hline pH & $\mathbf{1 . 9 1}$ & $\mathbf{0 . 1 8 6}$ & 52.93 & $<0.0001$ & $\mathbf{0 . 7 5}$ & $\mathbf{0 . 5 3 7}$ \\
Total organic C & 48.47 & $<0.0001$ & 281.08 & $<0.0001$ & 17.58 & $<0.0001$ \\
Total N & 7.99 & 0.012 & 160.85 & $<0.0001$ & 3.13 & 0.050 \\
Total P & $\mathbf{0 . 9 9}$ & $\mathbf{0 . 3 3 4}$ & 74.60 & $<0.0001$ & $\mathbf{0 . 8 8}$ & $\mathbf{0 . 4 7 3}$ \\
Total K & $\mathbf{2 . 7 9}$ & $\mathbf{0 . 1 1 4}$ & $\mathbf{1 . 2 1}$ & $\mathbf{0 . 3 3 9}$ & $\mathbf{1 . 0 9}$ & $\mathbf{0 . 3 8 1}$ \\
Inorganic N & 6.01 & 0.026 & 73.66 & $<0.0001$ & 8.80 & 0.001 \\
Available P & 11.45 & 0.004 & 184.96 & $<0.0001$ & 4.429 & 0.019 \\
Available K & 4.37 & 0.049 & 62.53 & $<0.0001$ & 4.08 & 0.025 \\
DOC & 47.75 & $<0.0001$ & 78.20 & $<0.0001$ & 10.60 & 0.0004 \\
DON & 29.23 & 0.0001 & 65.80 & $<0.0001$ & 7.23 & 0.003 \\
Soil water content & 6.55 & 0.021 & 38.72 & $<0.0001$ & $\mathbf{3 . 0 7}$ & $\mathbf{0 . 0 5 8}$ \\
\hline
\end{tabular}
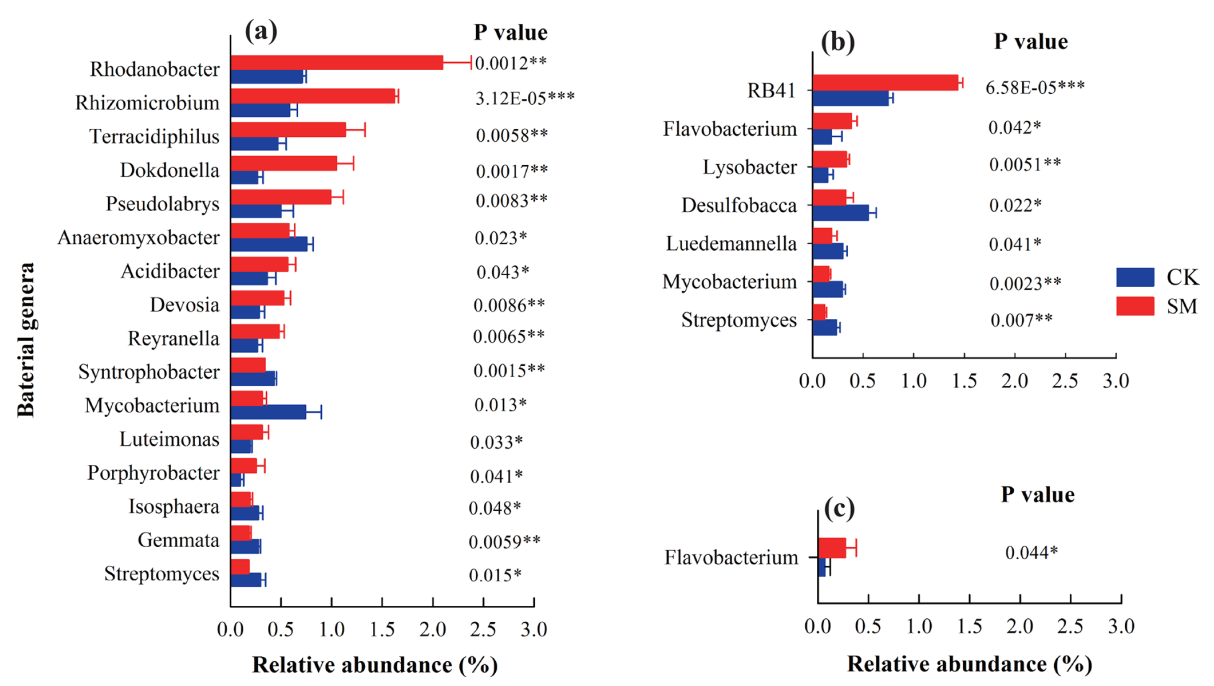

Figure 1. Bacterial genera that had significantly different relative abundances under CK and SM treatments at $0-5 \mathrm{~cm}(\mathbf{a}), 10-20 \mathrm{~cm}(\mathbf{b})$, and 20-30 cm (c) determined using $t$-tests with $95 \%$ confidence intervals. CK, no-till with straw removal; SM, no-till with straw mulching.

munities between CK and SM occurred at $0-5 \mathrm{~cm}$ from the PCoA plot. The results of Adonis analyses showed that bacterial communities under SM treatment were marginally but significantly different (Adonis $R^{2}=0.61, P=0.10$ ) from those under $\mathrm{CK}$ treatment at $0-5 \mathrm{~cm}$. A similar difference was observed between the two treatments at $10-20 \mathrm{~cm}$ (Adonis $R^{2}=0.44, P=0.10$ ). There was no significant difference between SM and CK bacterial communities at $5-10 \mathrm{~cm}$ (Adonis $R^{2}=0.11, P=0.60$ ) or $20-30 \mathrm{~cm}$ (Adonis $R^{2}=$ $0.19, P=0.30$ ). In addition, soil bacterial communities were significantly different among the four soil depths under both the CK (Adonis $R^{2}=0.76, P=0.0003$ ) and SM (Adonis $\left.R^{2}=0.88, P=0.0002\right)$ treatments.

\subsection{Relationships between soil bacterial characteristics and physicochemical properties}

Pearson's correlation analysis demonstrated that bacterial abundance, as determined by qPCR, was significantly correlated with the soil's total organic C, total N, DOC, DON, total and available $\mathrm{P}$, available $\mathrm{K}$, and water content (Table $\mathrm{S} 1$ in the Supplement).

To explore possible relationships between soil physicochemical properties and the structure of microbial communities, an RDA was conducted using all OTU and environmental variables (Fig. 3). Figure 3a, b, c, and d show that the first two axes explained $51.11 \%$ and $21.17 \%, 52.51 \%$ and $20.95 \%, 50.20 \%$ and $22.91 \%$, and $53.39 \%$ and $19.94 \%$ of the total variation in the bacterial communities between $\mathrm{CK}$ and SM at the four soil depths, respectively. The con- 
Table 2. Soil physicochemical properties at different soil depths under SM and CK treatment. CK, no-till with straw removal; SM, no-till with straw mulching. Data are means \pm standard deviations, $n=3$. Different capital letters indicate significant differences $(P<0.05)$ among the four depths; ${ }^{*}$ indicates significant differences $(P<0.05)$ among the two straw managements within each depth (Duncan's test). DOC, dissolved organic carbon; DON, dissolved organic nitrogen.

\begin{tabular}{|c|c|c|c|c|c|}
\hline \multirow{2}{*}{$\begin{array}{l}\text { Physicochemical } \\
\text { properties }\end{array}$} & \multirow[t]{2}{*}{ Treatment } & \multicolumn{4}{|c|}{ Soil depth gradient } \\
\hline & & $0-5 \mathrm{~cm}$ & $5-10 \mathrm{~cm}$ & $10-20 \mathrm{~cm}$ & $20-30 \mathrm{~cm}$ \\
\hline \multirow[t]{3}{*}{$\mathrm{pH}$} & CK & $5.27 \pm 0.19$ & $6.04 \pm 0.30$ & $6.63 \pm 0.36$ & $7.11 \pm 0.36$ \\
\hline & SM & $4.90 \pm 0.21$ & $5.76 \pm 0.40$ & $6.48 \pm 0.26$ & $7.23 \pm 0.26$ \\
\hline & & $5.09 \pm 0.27 \mathrm{~A}$ & $5.90 \pm 0.35 \mathrm{~B}$ & $6.56 \pm 0.29 C$ & $7.17 \pm 0.29 \mathrm{D}$ \\
\hline \multirow{3}{*}{$\begin{array}{l}\text { Total organic } \mathrm{C} \\
\left(\mathrm{g} \mathrm{kg}^{-1}\right)\end{array}$} & CK & $23.01 \pm 0.15^{*}$ & $19.42 \pm 1.23^{*}$ & $14.22 \pm 2.23$ & $6.90 \pm 1.19$ \\
\hline & SM & $33.24 \pm 1.47$ & $22.26 \pm 0.25$ & $15.76 \pm 1.41$ & $7.15 \pm 0.43$ \\
\hline & & $28.13 \pm 5.73 \mathrm{~A}$ & $20.84 \pm 1.75 B$ & $14.99 \pm 1.87 \mathrm{C}$ & $7.03 \pm 0.81 \mathrm{D}$ \\
\hline \multirow{3}{*}{$\begin{array}{l}\text { Total N } \\
\left(\mathrm{g} \mathrm{kg}^{-1}\right)\end{array}$} & $\mathrm{CK}$ & $2.84 \pm 0.10^{*}$ & $2.13 \pm 0.34$ & $1.54 \pm 0.27$ & $0.62 \pm 0.10$ \\
\hline & SM & $3.50 \pm 0.18$ & $2.39 \pm 0.17$ & $1.54 \pm 0.25$ & $0.66 \pm 0.11$ \\
\hline & & $3.17 \pm 0.38 \mathrm{~A}$ & $2.26 \pm 0.28 \mathrm{~B}$ & $1.54 \pm 0.23 \mathrm{C}$ & $0.64 \pm 0.10 \mathrm{D}$ \\
\hline \multirow{3}{*}{$\begin{array}{l}\text { Total P } \\
\left(\mathrm{g} \mathrm{kg}^{-1}\right)\end{array}$} & $\mathrm{CK}$ & $0.88 \pm 0.13$ & $0.67 \pm 0.02$ & $0.43 \pm 0.11$ & $0.22 \pm 0.04$ \\
\hline & SM & $0.86 \pm 0.02$ & $0.74 \pm 0.09$ & $0.53 \pm 0.10$ & $0.20 \pm 0.04$ \\
\hline & & $0.87 \pm 0.08 \mathrm{~A}$ & $0.70 \pm 0.07 \mathrm{~B}$ & $0.48 \pm 0.11 \mathrm{C}$ & $0.21 \pm 0.04 \mathrm{D}$ \\
\hline \multirow{3}{*}{$\begin{array}{l}\text { Total K } \\
\left(\mathrm{g} \mathrm{kg}^{-1}\right)\end{array}$} & $\mathrm{CK}$ & $12.42 \pm 0.38$ & $12.40 \pm 0.42$ & $11.75 \pm 0.30$ & $11.81 \pm 0.62$ \\
\hline & SM & $12.44 \pm 0.34$ & $12.55 \pm 0.58$ & $12.80 \pm 1.00$ & $12.07 \pm 0.27$ \\
\hline & & $12.43 \pm 0.33 \mathrm{~A}$ & $12.48 \pm 0.46 \mathrm{~A}$ & $12.28 \pm 0.88 \mathrm{~A}$ & $11.94 \pm 0.45 \mathrm{~A}$ \\
\hline \multirow{3}{*}{$\begin{array}{l}\text { Inorganic } \mathrm{N} \\
\left(\mathrm{mg} \mathrm{kg}^{-1}\right)\end{array}$} & CK & $21.43 \pm 1.02 *$ & $18.33 \pm 2.25$ & $14.21 \pm 2.53$ & $11.31 \pm 1.06$ \\
\hline & SM & $29.05 \pm 0.83$ & $16.64 \pm 2.42$ & $14.45 \pm 1.52$ & $11.89 \pm 0.41$ \\
\hline & & $25.24 \pm 4.25 \mathrm{~A}$ & $17.49 \pm 2.29 B$ & $14.33 \pm 1.87 \mathrm{C}$ & $11.60 \pm 0.79 \mathrm{D}$ \\
\hline \multirow{3}{*}{$\begin{array}{l}\text { Available P } \\
\left(\mathrm{mg} \mathrm{kg}^{-1}\right)\end{array}$} & $\mathrm{CK}$ & $94.49 \pm 7.59^{*}$ & $39.30 \pm 4.11$ & $14.74 \pm 3.70$ & $2.43 \pm 2.48$ \\
\hline & SM & $126.63 \pm 17.52$ & $53.74 \pm 14.21$ & $17.06 \pm 0.81$ & $1.60 \pm 0.87$ \\
\hline & & $110.55 \pm 21.34 \mathrm{~A}$ & $46.52 \pm 12.25 \mathrm{~B}$ & $15.90 \pm 2.71 \mathrm{C}$ & $2.01 \pm 1.73 \mathrm{D}$ \\
\hline \multirow{3}{*}{$\begin{array}{l}\text { Available K } \\
\left(\mathrm{mg} \mathrm{kg}^{-1}\right)\end{array}$} & $\mathrm{CK}$ & $152.33 \pm 15.93 *$ & $107.85 \pm 3.08$ & $103.37 \pm 1.55$ & $103.70 \pm 5.25$ \\
\hline & SM & $183.72 \pm 13.09$ & $115.88 \pm 13.95$ & $100.31 \pm 3.93$ & $100.84 \pm 9.81$ \\
\hline & & $168.02 \pm 21.58 \mathrm{~A}$ & $111.86 \pm 10.05 \mathrm{~B}$ & $101.83 \pm 3.16 \mathrm{~B}$ & $102.26 \pm 7.21 \mathrm{~B}$ \\
\hline \multirow{3}{*}{$\begin{array}{l}\text { DOC } \\
\left(\mathrm{mg} \mathrm{kg}^{-1}\right)\end{array}$} & $\mathrm{CK}$ & $41.42 \pm 5.74 *$ & $35.05 \pm 4.38^{*}$ & $20.59 \pm 1.24 *$ & $12.69 \pm 6.23$ \\
\hline & SM & $73.01 \pm 9.22$ & $55.41 \pm 1.99$ & $36.31 \pm 8.04$ & $8.48 \pm 2.88$ \\
\hline & & $57.21 \pm 18.62 \mathrm{~A}$ & $45.23 \pm 11.54 \mathrm{~B}$ & $28.45 \pm 10.03 \mathrm{C}$ & $10.58 \pm 4.92 \mathrm{D}$ \\
\hline \multirow{3}{*}{$\begin{array}{l}\mathrm{DON} \\
\left(\mathrm{mg} \mathrm{kg}^{-1}\right)\end{array}$} & CK & $16.11 \pm 1.89^{*}$ & $17.29 \pm 3.69$ & $12.33 \pm 0.85^{*}$ & $4.97 \pm 1.21$ \\
\hline & SM & $26.22 \pm 2.51$ & $18.08 \pm 2.24$ & $18.36 \pm 1.21$ & $5.98 \pm 0.94$ \\
\hline & & $21.16 \pm 5.89 \mathrm{~A}$ & $17.68 \pm 2.77 \mathrm{~B}$ & $15.34 \pm 3.43 \mathrm{~B}$ & $5.48 \pm 1.12 \mathrm{C}$ \\
\hline \multirow{3}{*}{$\begin{array}{l}\text { Soil water content } \\
(\%)\end{array}$} & $\mathrm{CK}$ & $16.99 \pm 0.69^{*}$ & $17.46 \pm 0.77$ & $15.21 \pm 0.66$ & $12.68 \pm 0.81$ \\
\hline & $\mathrm{SM}$ & $19.03 \pm 0.89$ & $16.71 \pm 0.73$ & $16.20 \pm 0.68$ & $13.81 \pm 1.18$ \\
\hline & & $18.01 \pm 1.32 \mathrm{~A}$ & $17.09 \pm 0.79 \mathrm{~A}$ & $15.71 \pm 0.80 \mathrm{~B}$ & $13.25 \pm 1.10 \mathrm{C}$ \\
\hline
\end{tabular}

tributions made by specific soil environmental factors varied with soil depth. Soil DOC $(F=4.1, P=0.001)$, total organic $\mathrm{C}(F=3.5, P=0.049)$, and $\mathrm{pH}(F=2.3, P=0.027)$ had significant effects on bacterial communities between the two treatments at $0-5 \mathrm{~cm}$, whereas only soil $\mathrm{pH}(F=4.4$, $P=0.015)$ had a significant effect at $5-10 \mathrm{~cm}$. At $10-20 \mathrm{~cm}$, soil pH $(F=3.1, P=0.022)$ and total organic $\mathrm{C}(F=2.6$, $P=0.038)$ had the most significant effects, and at $20-30 \mathrm{~cm}$, soil inorganic $\mathrm{N}(F=4.3, P=0.003), \mathrm{pH}(F=3, P=$
0.027), DON ( $F=2.7, P=0.032)$, and total $\mathrm{N}(F=2.7$, $P=0.030)$ most influenced soil bacterial communities. 
Table 3. Two-way ANOVA analysis of soil bacterial properties at four depths under two straw management strategies, each with three replicates. The data in bold indicate soil bacterial properties that were not affected by straw management strategy, soil depth, or their interaction $(P>0.05)$.

\begin{tabular}{lrr|r|r|rr}
\hline Bacterial properties & \multicolumn{2}{c|}{ Straw } & \multicolumn{2}{c|}{ Depth } & \multicolumn{2}{c}{ Straw $\times$ Depth } \\
\cline { 2 - 7 } & \multicolumn{2}{c|}{$F$} & $P$ & $F$ & $P$ & $F$ \\
\hline Copy number of 16S rRNA gene & 11.59 & 0.004 & 41.38 & $<0.0001$ & 4.51 & 0.018 \\
Shannon & $\mathbf{1 . 1 5}$ & $\mathbf{0 . 2 9 9}$ & 11.37 & 0.0003 & 3.21 & 0.050 \\
Shannon's evenness & $\mathbf{0 . 1 4}$ & $\mathbf{0 . 7 1 2}$ & 17.04 & $<0.0001$ & $\mathbf{3 . 1 1}$ & $\mathbf{0 . 0 5 6}$ \\
Chao1 & $\mathbf{3 . 1 1}$ & $\mathbf{0 . 0 9 7}$ & 4.09 & 0.025 & $\mathbf{0 . 6 8}$ & $\mathbf{0 . 5 7 7}$ \\
Proteobacteria & 13.32 & 0.002 & 17.69 & $<0.0001$ & $\mathbf{2 . 5 0}$ & $\mathbf{0 . 0 9 6}$ \\
Actinobacteria & 9.53 & 0.007 & 7.90 & 0.0019 & $\mathbf{1 . 3 2}$ & $\mathbf{0 . 3 0 2}$ \\
Acidobacteria & 20.27 & 0.0004 & 24.85 & $<0.0001$ & $\mathbf{1 . 9 4}$ & $\mathbf{0 . 1 6 5}$ \\
Chloroflexi & 14.87 & 0.001 & 24.68 & $<0.0001$ & $\mathbf{0 . 6 0}$ & $\mathbf{0 . 6 2 6}$ \\
Planctomycetes & $\mathbf{0 . 0 5}$ & $\mathbf{0 . 8 3 3}$ & 11.22 & 0.0003 & $\mathbf{0 . 5 4}$ & $\mathbf{0 . 6 6 4}$ \\
Nitrospirae & $\mathbf{0 . 0 2}$ & $\mathbf{0 . 8 9 4}$ & 34.12 & $<0.0001$ & $\mathbf{1 . 2 7}$ & $\mathbf{0 . 3 1 7}$ \\
Bacteroidetes & 20.28 & 0.0004 & 30.74 & $<0.0001$ & $\mathbf{1 . 8 6}$ & $\mathbf{0 . 1 7 7}$ \\
Firmicutes & $\mathbf{3 . 1 5}$ & $\mathbf{0 . 0 9 5}$ & $\mathbf{2 . 2 7}$ & $\mathbf{0 . 1 2 0}$ & $\mathbf{1 . 9 1}$ & $\mathbf{0 . 1 6 9}$ \\
Gemmatimonadetes & $\mathbf{0 . 1 7}$ & $\mathbf{0 . 6 8 6}$ & 14.09 & 0.0001 & $\mathbf{0 . 0 4}$ & $\mathbf{0 . 9 9 0}$ \\
Cyanobacteria & 22.41 & 0.0002 & 69.95 & $<0.0001$ & 18.48 & $<0.0001$ \\
Unclassified & $\mathbf{0 . 3 7}$ & $\mathbf{0 . 5 5 3}$ & 35.70 & $<0.0001$ & $\mathbf{2 . 3 1}$ & $\mathbf{0 . 1 1 5}$ \\
Verrucomicrobia & $\mathbf{1 . 4 3}$ & $\mathbf{0 . 2 4 9}$ & $\mathbf{1 . 4 0}$ & $\mathbf{0 . 2 7 8}$ & $\mathbf{1 . 3 2}$ & $\mathbf{0 . 3 0 4}$ \\
Latescibacteria & 4.73 & 0.045 & 33.21 & $<0.0001$ & $\mathbf{2 . 0 8}$ & $\mathbf{0 . 1 4 3}$ \\
Others & $\mathbf{0 . 7 1}$ & $\mathbf{0 . 4 1 2}$ & 58.55 & $<0.0001$ & $\mathbf{0 . 8 3}$ & $\mathbf{0 . 4 9 7}$ \\
\hline
\end{tabular}

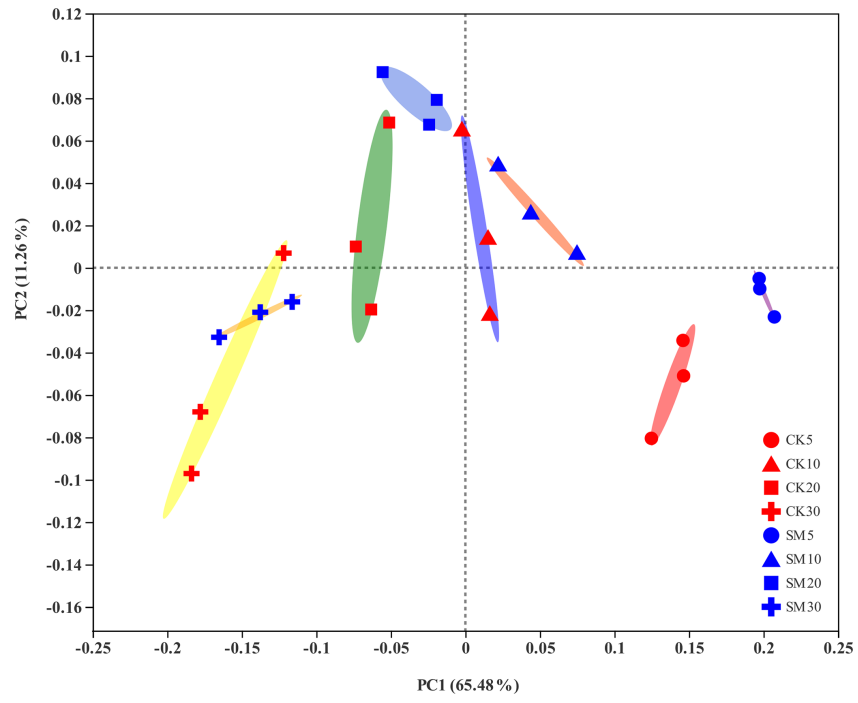

Figure 2. Principal coordinate analysis (PCoA) plot of soil bacterial communities based on OTUs from 24 samples. CK5, CK10, CK20, and CK30 represent soils sampled at 0-5, 5-10, 10-20, and 20-30 cm, respectively, from the straw removal group. SM5, SM10, SM20, and SM30 represent soil sampled at 0-5, 5-10, 10-20, and $20-30 \mathrm{~cm}$, respectively, from the straw mulching group. The ellipses serve as visual aids to distinguish between different straw treatments at different soil depths and have no statistical meaning.

\section{Discussion}

\subsection{Straw mulching changed soil physicochemical properties with soil depth}

Our study demonstrated that compared to straw removal, long-term straw mulching increased contents of total N, inorganic $\mathrm{N}$, available $\mathrm{P}$, and available $\mathrm{K}$ at $0-5 \mathrm{~cm}$, water content at $0-5 \mathrm{~cm}$, and total organic $\mathrm{C}$ at $0-5$ and $5-10 \mathrm{~cm}$. These results may be explained by the fact that the straw was mulched at the soil surface rather than being incorporated into the soil, leading to large amounts of $\mathrm{C}$ and nutrients being released at the soil surface as the straw decomposed (Akhtar et al., 2018; Blanco-Canqui and Lal, 2007). Furthermore, the decrease in gaseous $\mathrm{N}$ loss through ammonia volatilization and denitrification caused by straw mulching may have also contributed to the accumulation of soil $\mathrm{N}$ fractions (Cao et al., 2018). During straw decomposition, large amounts of soluble organic matter, such as starch, protein, and monosaccharides, can be leached and do accumulate in the subsoil (BlancoCanqui and Lal, 2007), which may have increased soil DOC and DON at $0-20 \mathrm{~cm}$. For soil water content, mulched straw can reduce water evaporation and increase water retention (Palm et al., 2014; W. Wang et al., 2019). However, there was no significant difference in $\mathrm{pH}$, total $\mathrm{P}$, or total $\mathrm{K}$ levels between CK and SM. Similarities in $\mathrm{pH}$ values after straw mulching are consistent with reports by Wang et al. (2020). Unchanged soil total P and total K may be explained by the high levels of these elements in the soil (Dong et al., 2012; Zhang et al., 2016). 
Table 4. Soil bacterial properties at different soil depths under SM and CK treatment. CK, no-till with straw removal; SM, no-till with straw mulching. Data are means \pm standard deviations, $n=3$. Different capital letters indicate significant differences $(P<0.05)$ among the four depths; * indicates significant differences $(P<0.05)$ among the two straw management strategies within each depth (Duncan's test).

\begin{tabular}{|c|c|c|c|c|c|}
\hline \multirow[t]{2}{*}{ Bacterial properties } & \multirow[t]{2}{*}{ Treatment } & \multicolumn{4}{|c|}{ Soil depth gradient } \\
\hline & & $0-5 \mathrm{~cm}$ & $5-10 \mathrm{~cm}$ & $10-20 \mathrm{~cm}$ & $20-30 \mathrm{~cm}$ \\
\hline \multirow[t]{3}{*}{ Copy number of $16 \mathrm{~S}$ rRNA gene } & CK & $14.77 \pm 2.69 *$ & $7.18 \pm 2.59$ & $6.30 \pm 1.75$ & $2.10 \pm 0.54$ \\
\hline & SM & $24.65 \pm 3.93$ & $13.59 \pm 4.98$ & $6.12 \pm 2.65$ & $1.97 \pm 1.34$ \\
\hline & & $19.71 \pm 6.19 \mathrm{~A}$ & $10.38 \pm 4.99 \mathrm{~B}$ & $6.22 \pm 2.01 \mathrm{C}$ & $2.03 \pm 0.92 \mathrm{D}$ \\
\hline \multirow[t]{3}{*}{ Shannon } & CK & $6.53 \pm 0.03 *$ & $6.38 \pm 0.08$ & $6.34 \pm 0.05$ & $6.07 \pm 0.16$ \\
\hline & SM & $6.40 \pm 0.08$ & $6.42 \pm 0.09$ & $6.40 \pm 0.06$ & $6.27 \pm 0.12$ \\
\hline & & $6.46 \pm 0.09 \mathrm{~A}$ & $6.40 \pm 0.08 \mathrm{~A}$ & $6.37 \pm 0.06 \mathrm{~A}$ & $6.17 \pm 0.17 \mathrm{~B}$ \\
\hline \multirow[t]{3}{*}{ Shannon's evenness } & CK & $0.864 \pm 0.002 *$ & $0.844 \pm 0.006$ & $0.843 \pm 0.007$ & $0.816 \pm 0.016$ \\
\hline & SM & $0.852 \pm 0.007$ & $0.846 \pm 0.008$ & $0.842 \pm 0.004$ & $0.832 \pm 0.009$ \\
\hline & & $0.858 \pm 0.008 \mathrm{~A}$ & $0.845 \pm 0.006 \mathrm{~B}$ & $0.843 \pm 0.005 \mathrm{~B}$ & $0.824 \pm 0.015 \mathrm{C}$ \\
\hline \multirow[t]{3}{*}{ Chao1 } & CK & $2417 \pm 64$ & $2563 \pm 198$ & $2506 \pm 166$ & $2437 \pm 18$ \\
\hline & SM & $2421 \pm 46$ & $2714 \pm 74$ & $2689 \pm 146$ & $2472 \pm 185$ \\
\hline & & $2419 \pm 50 \mathrm{~A}$ & $2639 \pm 156 \mathrm{C}$ & $2597 \pm 172 B C$ & $2455 \pm 119 \mathrm{AB}$ \\
\hline \multirow[t]{3}{*}{ Proteobacteria } & $\mathrm{CK}$ & $32.11 \pm 0.82 *$ & $29.51 \pm 2.16$ & $29.08 \pm 1.78$ & $26.69 \pm 3.70$ \\
\hline & SM & $38.87 \pm 2.57$ & $31.31 \pm 0.71$ & $30.93 \pm 0.32$ & $28.06 \pm 1.36$ \\
\hline & & $35.49 \pm 4.08 \mathrm{~A}$ & $30.41 \pm 1.75 \mathrm{~B}$ & $30.00 \pm 1.53 \mathrm{~B}$ & $27.37 \pm 2.60 \mathrm{C}$ \\
\hline \multirow[t]{3}{*}{ Actinobacteria } & CK & $17.02 \pm 2.99$ & $12.57 \pm 2.44$ & $12.15 \pm 0.66^{*}$ & $10.32 \pm 1.62$ \\
\hline & SM & $12.66 \pm 1.82$ & $11.30 \pm 2.52$ & $8.83 \pm 0.56$ & $9.76 \pm 0.73$ \\
\hline & & $14.84 \pm 3.26 \mathrm{~A}$ & $11.94 \pm 2.32 \mathrm{~B}$ & $10.49 \pm 1.90 \mathrm{~B}$ & $10.04 \pm 1.16 \mathrm{~B}$ \\
\hline \multirow[t]{3}{*}{ Acidobacteria } & CK & $17.17 \pm 1.96$ & $19.56 \pm 0.56$ & $20.14 \pm 0.70^{*}$ & $14.32 \pm 1.30^{*}$ \\
\hline & SM & $21.23 \pm 2.25$ & $20.16 \pm 0.97$ & $22.52 \pm 0.28$ & $16.44 \pm 0.01$ \\
\hline & & $19.20 \pm 2.92 \mathrm{~B}$ & $19.86 \pm 0.78 \mathrm{BC}$ & $21.33 \pm 1.39 \mathrm{C}$ & $15.38 \pm 1.42 \mathrm{~A}$ \\
\hline \multirow[t]{3}{*}{ Chloroflexi } & CK & $13.82 \pm 1.37 *$ & $13.33 \pm 2.03$ & $14.63 \pm 1.84 *$ & $20.46 \pm 2.96$ \\
\hline & $\mathrm{SM}$ & $10.03 \pm 1.30$ & $12.02 \pm 1.25$ & $11.56 \pm 0.20$ & $18.10 \pm 0.99$ \\
\hline & & $11.92 \pm 2.40 \mathrm{~A}$ & $12.67 \pm 1.67 \mathrm{~A}$ & $13.10 \pm 2.05 \mathrm{~A}$ & $19.28 \pm 2.36 \mathrm{~B}$ \\
\hline \multirow[t]{3}{*}{ Planctomycetes } & $\mathrm{CK}$ & $4.29 \pm 0.50$ & $3.68 \pm 0.22$ & $4.16 \pm 0.28$ & $2.56 \pm 1.04$ \\
\hline & SM & $3.95 \pm 0.51$ & $3.76 \pm 0.07$ & $4.23 \pm 0.16$ & $2.93 \pm 0.40$ \\
\hline & & $4.12 \pm 0.49 \mathrm{~A}$ & $3.72 \pm 0.15 \mathrm{~A}$ & $4.20 \pm 0.21 \mathrm{~A}$ & $2.74 \pm 0.73 \mathrm{~B}$ \\
\hline \multirow[t]{3}{*}{ Nitrospirae } & CK & $5.25 \pm 1.17$ & $10.39 \pm 1.39$ & $8.50 \pm 1.40$ & $13.18 \pm 2.54$ \\
\hline & SM & $4.66 \pm 0.23$ & $10.26 \pm 0.93$ & $10.40 \pm 1.35$ & $12.29 \pm 0.66$ \\
\hline & & $4.96 \pm 0.82 \mathrm{~A}$ & $10.33 \pm 1.06 \mathrm{~B}$ & $9.45 \pm 1.61 \mathrm{~B}$ & $12.74 \pm 1.73 \mathrm{C}$ \\
\hline \multirow[t]{3}{*}{ Bacteroidetes } & $\mathrm{CK}$ & $1.74 \pm 0.21 *$ & $1.37 \pm 0.36$ & $0.78 \pm 0.16^{*}$ & $0.62 \pm 0.29$ \\
\hline & SM & $2.45 \pm 0.21$ & $1.67 \pm 0.39$ & $1.52 \pm 0.15$ & $0.78 \pm 0.22$ \\
\hline & & $2.09 \pm 0.43 \mathrm{~A}$ & $1.52 \pm 0.37 \mathrm{~B}$ & $1.15 \pm 0.43 \mathrm{C}$ & $0.70 \pm 0.25 \mathrm{D}$ \\
\hline \multirow[t]{3}{*}{ Firmicutes } & CK & $1.16 \pm 0.35$ & $1.48 \pm 0.31$ & $2.29 \pm 0.73$ & $1.35 \pm 0.59$ \\
\hline & SM & $1.12 \pm 0.34$ & $1.47 \pm 0.45$ & $1.23 \pm 0.31$ & $1.18 \pm 0.16$ \\
\hline & & $1.14 \pm 0.31 \mathrm{~A}$ & $1.48 \pm 0.35 \mathrm{AB}$ & $1.76 \pm 0.77 \mathrm{~B}$ & $1.26 \pm 0.40 \mathrm{AB}$ \\
\hline \multirow[t]{3}{*}{ Gemmatimonadetes } & $\mathrm{CK}$ & $1.40 \pm 0.21$ & $2.42 \pm 0.31$ & $2.31 \pm 0.32$ & $1.98 \pm 0.52$ \\
\hline & SM & $1.42 \pm 0.19$ & $2.42 \pm 0.32$ & $2.42 \pm 0.14$ & $2.05 \pm 0.24$ \\
\hline & & $1.41 \pm 0.18 \mathrm{~A}$ & $2.42 \pm 0.28 \mathrm{C}$ & $2.37 \pm 0.23 \mathrm{BC}$ & $2.01 \pm 0.37 \mathrm{~B}$ \\
\hline \multirow[t]{3}{*}{ Cyanobacteria } & CK & $1.25 \pm 0.29^{*}$ & $0.20 \pm 0.02$ & $0.10 \pm 0.05$ & $0.12 \pm 0.02^{*}$ \\
\hline & SM & $0.48 \pm 0.04$ & $0.15 \pm 0.03$ & $0.14 \pm 0.06$ & $0.06 \pm 0.02$ \\
\hline & & $0.87 \pm 0.46 \mathrm{~A}$ & $0.17 \pm 0.03 \mathrm{~B}$ & $0.12 \pm 0.05 \mathrm{~B}$ & $0.09 \pm 0.04 \mathrm{~B}$ \\
\hline \multirow[t]{3}{*}{ Unclassified } & CK & $1.27 \pm 0.30^{*}$ & $2.19 \pm 0.14$ & $2.08 \pm 0.18$ & $2.41 \pm 0.26$ \\
\hline & SM & $0.76 \pm 0.11$ & $2.05 \pm 0.20$ & $2.23 \pm 0.36$ & $2.63 \pm 0.42$ \\
\hline & & $1.01 \pm 0.34 \mathrm{~A}$ & $2.12 \pm 0.17 \mathrm{~B}$ & $2.15 \pm 0.27 \mathrm{~B}$ & $2.52 \pm 0.33 \mathrm{C}$ \\
\hline Verrucomicrobia & $\mathrm{CK}$ & $1.51 \pm 1.63$ & $0.42 \pm 0.23$ & $0.58 \pm 0.72$ & $0.13 \pm 0.07$ \\
\hline & SM & $0.34 \pm 0.02$ & $0.59 \pm 0.42$ & $0.21 \pm 0.03$ & $0.22 \pm 0.08$ \\
\hline & & $0.93 \pm 1.21 \mathrm{~A}$ & $0.50 \pm 0.31 \mathrm{~A}$ & $0.40 \pm 0.50 \mathrm{~A}$ & $0.17 \pm 0.08 \mathrm{~A}$ \\
\hline Latescibacteria & CK & $0.46 \pm 0.13$ & $1.32 \pm 0.24$ & $1.31 \pm 0.37$ & $1.38 \pm 0.19$ \\
\hline & $\mathrm{SM}$ & $0.56 \pm 0.03$ & $1.25 \pm 0.09$ & $1.81 \pm 0.11$ & $1.58 \pm 0.25$ \\
\hline & & $0.51 \pm 0.10 \mathrm{~A}$ & $1.29 \pm 0.17 \mathrm{~B}$ & $1.56 \pm 0.37 \mathrm{C}$ & $1.48 \pm 0.23 \mathrm{BC}$ \\
\hline Others & CK & $1.55 \pm 0.24$ & $1.55 \pm 0.16$ & $1.89 \pm 0.09$ & $4.49 \pm 1.05$ \\
\hline & SM & $1.47 \pm 0.19$ & $1.59 \pm 0.10$ & $1.96 \pm 0.24$ & $3.91 \pm 0.22$ \\
\hline & & $1.51 \pm 0.20 \mathrm{~A}$ & $1.57 \pm 0.12 \mathrm{~A}$ & $1.92 \pm 0.17 \mathrm{~A}$ & $4.20 \pm 0.75 \mathrm{~B}$ \\
\hline
\end{tabular}



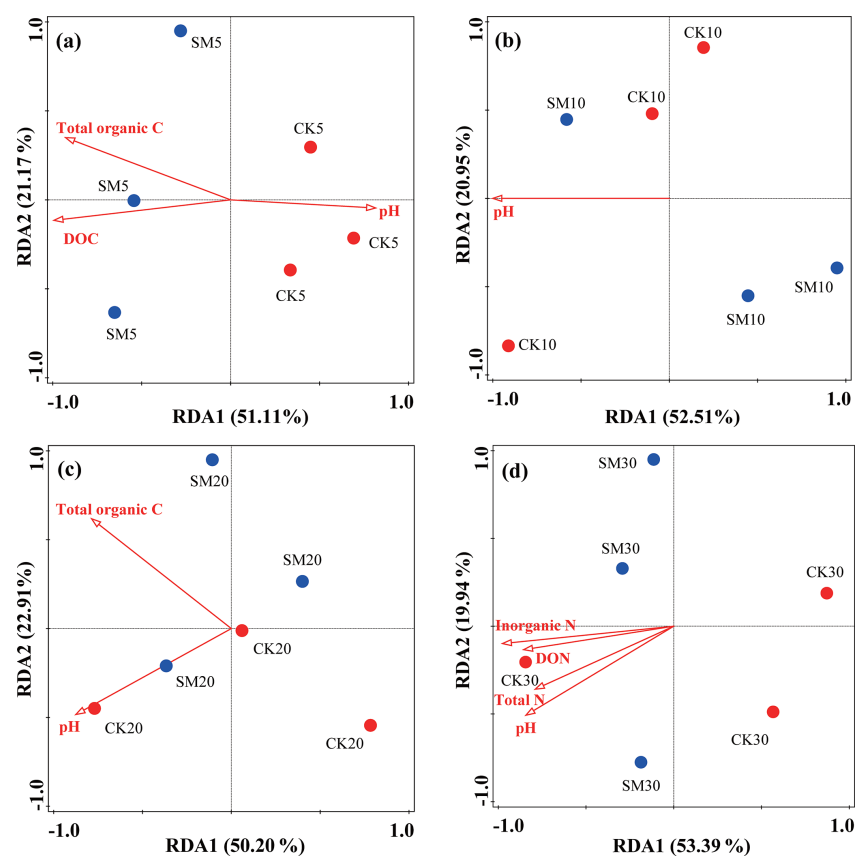

Figure 3. Redundancy analysis (RDA) of soil bacterial community changes at the OTU level and soil physicochemical property differences between CK and SM plots at 0-5 cm (a), 5-10 cm (b), 10$20 \mathrm{~cm}$ (c), and 20-30 cm (d). CK5, CK10, CK20, and CK30 represent soil sampled at $0-5,5-10,10-20$, and $20-30 \mathrm{~cm}$, respectively, from the straw removal group. SM5, SM10, SM20, and SM30 represent soil sampled at $0-5,5-10,10-20$, and $20-30 \mathrm{~cm}$, respectively, from the straw mulching group. DOC, dissolved organic carbon; DON, dissolved organic nitrogen.

The results of the present study showed that the soil's total organic $\mathrm{C}$, total $\mathrm{N}$, total $\mathrm{P}$, inorganic $\mathrm{N}$, available $\mathrm{P}$, available K, DOC, DON, and water content decreased but $\mathrm{pH}$ increased with increasing soil depth, which was partly consistent with our hypothesis. One reason for this was that most crop roots are distributed at depths of $0-10 \mathrm{~cm}$ or $0-20 \mathrm{~cm}$ (Li et al., 2020), and root exudates and $\mathrm{C}$ released after root decomposition lead to higher total organic $\mathrm{C}$ and DOC contents in the topsoil than in the subsoil. Beyond the effects of roots, inorganic $\mathrm{N}, \mathrm{P}$, and $\mathrm{K}$ fertilizers were applied to the soil surface without tillage, and these elements were initially enriched in the topsoil but decreased with soil depth. Large amounts of $\mathrm{N}$ fertilizer over a long period of time could result in soil acidification (Guo et al., 2010), which results in a lower $\mathrm{pH}$ value in the topsoil than in the subsoil. The total $\mathrm{K}$ content did not change with soil depth, mainly because of its high levels in the studied soil.

\subsection{Straw mulching altered soil bacterial abundance and communities with soil depth}

Soil bacterial communities play an important role in regulating soil processes, and the biomass and composition of soil bacteria determine the sustainability of agricultural soils (Segal et al., 2017). Our results provide strong support for the view of Bai et al. (2018), who showed that straw can provide energy and nutrients for soil bacterial growth. Compared to CK treatment, straw mulching increased soil organic C, soil nutrients, and water moisture, which favored soil bacterial abundance, especially in topsoil (Tables S1, 3). Similar results were also reported by Ji et al. (2018). Previous studies reported that soil moisture (Brockett et al., 2012), $\mathrm{C}$ and/or N availability (van Leeuwen et al., 2017), and total P (Song et al., 2020) were significantly and positively correlated with soil bacterial abundance. Meanwhile, most soil bacterial abundance-related physicochemical parameters were reduced in deeper soil layers, which largely contributed to the decreasing soil bacterial abundance with soil depth (Tables 3 and 4). This was consistent with the results of van Leeuwen et al. (2017).

Soil bacteria can be divided into copiotrophic and oligotrophic groups based on their performance in different substrates (Fierer et al., 2007, 2012). Straw mulching produced a nutrient-rich soil environment, which benefits copiotroph bacterial growth and leads to a shift in the predominant bacterial community (Fierer et al., 2012). In addition, high soil inorganic $\mathrm{N}$ content decreases bacterial diversity (Yu et al., 2019; Zhao et al., 2019). These factors contributed to the reduced Shannon diversity and Shannon's evenness index values at $0-5 \mathrm{~cm}$ after straw mulching. Soil biodiversity is important for maintaining ecosystem function (Wagg et al., 2014), and sustainable agriculture requires adoption of management practices that preserve or increase microbial diversity rather than destroy or threaten it (Pastorelli et al., 2013). Consequently, inorganic $\mathrm{N}$ fertilizer should be reduced under straw mulching, which may further contribute to maintaining or improving bacterial diversity.

Bacterial phyla demonstrated different responses to straw management strategies and soil depths. The relative abundances of copiotrophic bacteria, such as Proteobacteria, Actinobacteria, and Bacteroidetes, decreased with soil depth due to their preference for the abundant soil resources in topsoil (Fierer et al., 2007, 2012; Liang et al., 2018; Ling et al., 2017). As a result, compared with CK, straw mulching increased soil $\mathrm{C}$ and nutrients, thereby increasing the relative abundances of Proteobacteria and Bacteroidetes (Fierer et al., 2007, 2012; Liang et al., 2018; Ling et al., 2017). Bacteroidetes are involved in hemicellulose breakdown, and mulched straw stimulated Bacteroidetes proliferation during straw decomposition (Wegner and Liesack, 2016). Chloroflexi is classified as an oligotrophic group, and enriched soil nutrients restricted Chloroflexi growth in topsoil or after straw mulching, which is in agreement with the results of Liang et al. (2018). Notably, soil nutrient condition was not the only factor influencing the proliferation of bacterial phyla such as Actinobacteria and Acidobacteria. The phylum Actinobacteria was classified as copiotrophic by Fierer et al. (2012), but straw mulching decreased Actinobacteria 
in our study, similar to the observations of other studies (Calleja-Cervantes et al., 2015; Hao et al., 2019; Liang et al., 2018). One possible reason is that straw mulching increased soil water content and reduced soil oxygen content, whereas most Actinobacteria favor aerobic environments (Hamamura et al., 2006). Although Acidobacteria is classified as oligotrophic, it is involved in hemicellulose breakdown (Wegner and Liesack, 2016), leading to increases in its relative abundance after straw mulching.

Our results confirmed that straw return changed certain soil bacteria genera associated with $\mathrm{C}$ and $\mathrm{N}$ cycles (Shang et al., 2011; Wang et al., 2012; Xu et al., 2017). For example, straw mulching favored Rhodanobacter growth, which is the dominant bacterial genus containing denitrifying species and is positively associated in $\mathrm{N}_{2} \mathrm{O}$ emissions (Huang et al., 2019). Similarly, the relative abundances of the genera $R h i$ zomicrobium, Dokdonella, Reyranella, and Luteimonas, Ncycling-related bacterial taxa containing denitrifiers, were increased in straw mulched soil (Chen et al., 2020a; Nie et al., 2018; D. Wang et al., 2019; Wolff et al., 2018). Terracidiphilus, Acidibacter, Flavobacterium, and Lysobacter are involved in the degradation of plant-derived biopolymers (Garcia-Fraile et al., 2016), organic substrates (Ai et al., 2018), labile carbon (Nan et al., 2020), and macromolecules (Maarastawi et al., 2018), and large C-based materials from mulched straw increased their relative abundances. Although little is known about the ecology of Pseudolabrys, its relative abundance was increased in soil after compost application (Joa et al., 2014). D. Wang et al. (2019) found that organic carbon can inhibit the growth of chemolithotrophic bacteria and favor Dokdonella. According to Foesel et al. (2013), Blastocatella fastidiosa is the only known isolate from $R B 41$ and prefers protein-containing substrates. Straw mulching may increase the contents of these substrates and, therefore, the relative abundance of $R B 41$.

RDA results suggested that the key soil physicochemical parameters distinguishing soil bacteria between SM and CK changed with soil depth, which was consistent with our hypothesis. However, the main parameters were soil $\mathrm{pH}$ and different $\mathrm{N}$ and organic $\mathrm{C}$ fractions. A similar relationship was found in other studies (Schreiter et al., 2014; Sun et al., 2015). Schreiter. et al. (2014) demonstrated that the soil's total organic $\mathrm{C}, \mathrm{pH}$, and some available nutrients were closely related to soil bacterial communities. Sun et al. (2015) proposed that soil $\mathrm{pH}$ was the driving factor in shaping bacterial community structure after straw addition.

\section{Conclusions}

In this study, we investigated the effects of long-term straw mulching on soil properties along a soil depth gradient under a no-till rice-wheat rotation system. The results showed that the soil's total organic $\mathrm{C}$, total $\mathrm{N}$, total $\mathrm{P}$, inorganic $\mathrm{N}$, available $\mathrm{P}$, available K, DOC, DON, water content, and bac- terial abundance decreased but soil $\mathrm{pH}$ increased with soil depth. Compared with CK, straw mulching increased the soil's total organic C at $0-10 \mathrm{~cm}$, the soil's total and inorganic $\mathrm{N}$, available $\mathrm{P}$ and $\mathrm{K}$, and water content at $0-5 \mathrm{~cm}$, DOC and DON at $0-20 \mathrm{~cm}$, and bacterial abundance $0-5 \mathrm{~cm}$ but reduced Shannon diversity and Shannon's evenness of the bacterial community at $0-5 \mathrm{~cm}$. Regarding bacterial communities, straw mulching increased the relative abundances of Proteobacteria, Bacteroidetes, and Acidobacteria, but reduced those of Actinobacteria, Chloroflexi, and Cyanobacteria. Additionally, straw mulching increased some C- and $\mathrm{N}$-cycling genera, such as Rhodanobacter, Rhizomicrobium, Terracidiphilus, Dokdonella, Pseudolabrys, Acidibacter, Devosia, Reyranella, Luteimonas, and Porphyrobacter. PCoA showed that the largest difference in the composition of soil bacterial communities between $\mathrm{CK}$ and SM occurred at 0$5 \mathrm{~cm}$. Soil $\mathrm{pH}, \mathrm{N}$, and organic $\mathrm{C}$ fractions were the major drivers shaping soil bacterial communities. Overall, straw mulching is highly recommended under a no-till system in southwestern China because of its benefits for soil fertility and bacterial abundance. However, to maintain or increase soil bacterial Shannon diversity, the amount of inorganic N fertilizer could be reduced after straw mulching in future studies.

Data availability. All data are available, and interested parties may email the corresponding author for data sets. The sequencing data have been submitted to the NCBI Sequence Read Archive database (SRA accession PRJNA625832, https://www.ncbi.nlm. nih.gov/sra/PRJNA625832, last access: 3 September 2021).

Supplement. The supplement related to this article is available online at: https://doi.org/10.5194/soil-7-595-2021-supplement.

Author contributions. $\mathrm{ZZ}$ analyzed the data and wrote the manuscript. ZL and ZC helped to analyze the data and write the manuscript. ZZ, KC, and XZ collected the soil samples. ZZ, HY, SG, YS, and HF determined the soil attributes. QC, ST, MH, and YQ installed the experiment and reviewed the manuscript. All authors approved the final version of the manuscript.

Competing interests. The authors declare that they have no conflict of interest.

Disclaimer. Publisher's note: Copernicus Publications remains neutral with regard to jurisdictional claims in published maps and institutional affiliations. 
Acknowledgements. We thank International Science Editing (http://www.internationalscienceediting.com, last access: 28 July 2021) for editing this manuscript.

Financial support. This work was supported by the National Natural Science Foundation of China (grant no. 41807103), Sichuan Science and Technology Program (grant no. 2019YJ0609), the National Key R\&D Program of China (grant nos. 2016YFD0300907 and 2016YFE0112700), the Youth Foundation of Sichuan Academy of Agricultural Sciences (grant no. 2018QNJJ-017), and the Open Foundation of State Key Laboratory of Soil and Sustainable Agriculture of China (grant no. Y20160021).

Review statement. This paper was edited by Ashish Malik and reviewed by João William Bossolani and two anonymous referees.

\section{References}

Ai, C., Zhang, S., Zhang, X., Guo, D., Zhou, W., and Huang, S.: Distinct responses of soil bacterial and fungal communities to changes in fertilization regime and crop rotation, Geoderma, 319, 156-166, https://doi.org/10.1016/j.geoderma.2018.01.010, 2018.

Akhtar, K., Wang, W., Ren, G., Khan, A., Feng, Y., and Yang, G.: Changes in soil enzymes, soil properties, and maize crop productivity under wheat straw mulching in Guanzhong, China, Soil Till. Res., 182, 94-102, https://doi.org/10.1016/j.still.2018.05.007, 2018.

Ashworth, A. J., DeBruyn, J. M., Allen, F. L., Radosevich, M., and Owens, P. R.: Microbial community structure is affected by cropping sequences and poultry litter under long-term no-tillage, Soil Biol. Biochem., 114, 210-219, https://doi.org/10.1016/j.soilbio.2017.07.019, 2017.

Bai, Z. G., Thomas, C., Ruiperez, G. M., Batjes, N. H., Mäder, P., Bünemann, E. K., de Goede, R., Brussaard, L., Xu, M., Ferreira, C. S. S., Reintam, E., Fan, H., Mihelič, R., Glavan, M., and Tóth, Z.: Effects of agricultural management practices on soil quality: a review of long-term experiments for Europe and China, Agr. Ecosyst. Environ., 265, 1-7, https://doi.org/10.1016/j.agee.2018.05.028, 2018.

Blanco-Canqui, H. and Lal, R.: Soil structure and organic carbon relationships following 10 years of wheat straw management in no-till, Soil Till. Res., 95, 240-254, https://doi.org/10.1016/j.still.2007.01.004, 2007.

Brockett, B. F., Prescott, C. E., and Grayston, S. J.: Soil moisture is the major factor influencing microbial community structure and enzyme activities across seven biogeoclimatic zones in western Canada, Soil Biol. Biochem., 44, 9-20, https://doi.org/10.1016/j.soilbio.2011.09.003, 2012.

Bu, R., Ren, T., Lei, M., Liu, B., Li, X., Cong, R., and Lu, J.: Tillage and straw-returning practices effect on soil dissolved organic matter, aggregate fraction and bacteria community under rice-rice-rapeseed rotation system, Agr. Ecosyst. Environ., 287, 106681, https://doi.org/10.1016/j.agee.2019.106681, 2020.

Calleja-Cervantes, M. E., Fernández-González, A. J., Irigoyen, I., Fernández-López, M., Aparicio-Tejo, P. M., and Menén- dez, S.: Thirteen years of continued application of composted organic wastes in a vineyard modify soil quality characteristics, Soil Biol. Biochem., 90, 241-254, https://doi.org/10.1016/j.soilbio.2015.07.002, 2015.

Cao, Y., Sun, H., Zhang, J., Chen, G., Zhu, H., Zhou, S., and Xiao, H.: Effects of wheat straw addition on dynamics and fate of nitrogen applied to paddy soils, Soil Till. Res., 178, 92-98, https://doi.org/10.1016/j.still.2017.12.023, 2018.

Caporaso, J. G., Lauber, C. L., Walters, W. A., Berg-Lyons, D., Huntley, J., Fierer, N., Owens, S. M., Betley, J., Fraser, L., Bauer, M., Gormley, N., Gilbert, J. A., Smith, G., and Knight, R.: Ultra-high-throughput microbial community analysis on the Illumina HiSeq and MiSeq platforms, ISME J., 6, 1621-1624, https://doi.org/10.1038/ismej.2012.8, 2012.

Chen, J., Wu, Q., Li, S., Ge, J., Liang, C., Qin, H., Xu, Q., and Fuhrmann, J. J.: Diversity and function of soil bacterial communities in response to long-term intensive management in a subtropical bamboo forest, Geoderma, 354, 113894, https://doi.org/10.1016/j.geoderma.2019.113894, 2019.

Chen, S., Qi, G., Ma, G., and Zhao, X.: Biochar amendment controlled bacterial wilt through changing soil chemical properties and microbial community, Microbiol. Res., 231, 126373, https://doi.org/10.1016/j.micres.2019.126373, 2020a.

Chen, Z., Wang, H., Liu, X., Zhao, X., Lu, D., Zhou, J., and $\mathrm{Li}, \mathrm{C}$.: Changes in soil microbial community and organic carbon fractions under short-term straw return in a rice-wheat cropping system, Soil Till. Res., 165, 121-127, https://doi.org/10.1016/j.still.2016.07.018, 2017.

Dai, X., Zhou, W., Liu, G., Liang, G., He, P., and Liu, Z.: Soil $\mathrm{C} / \mathrm{N}$ and $\mathrm{pH}$ together as a comprehensive indicator for evaluating the effects of organic substitution management in subtropical paddy fields after application of high-quality amendments, Geoderma, 337, 1116-1125, https://doi.org/10.1016/j.geoderma.2018.11.023, 2019.

Dong, W., Zhang, X., Wang, H., Dai, X., Sun, X., Qiu, W., and Yang, F.: Effect of different fertilizer application on the soil fertility of paddy soils in red soil region of southern China, PLoS One, 7, 44504, https://doi.org/10.1371/journal.pone.0044504, 2012.

Duval, M. E., Galantini, J. A., Capurro, J. E., and Martinez, J. M.: Winter cover crops in soybean monoculture: Effects on soil organic carbon and its fractions, Soil Till. Res., 161, 95-105, https://doi.org/10.1016/j.still.2016.04.006, 2016.

Fan, X. and Xing, P.: The vertical distribution of sediment archaeal community in the "black bloom" disturbing Zhushan bay of lake Taihu, Archaea, 2016, 8232135, https://doi.org/10.1155/2016/8232135, 2016.

Fierer, N., Schimel, J. P., and Holden, P. A.: Variations in microbial community composition through two soil depth profiles, Soil Biol. Biochem., 35, 167-176, https://doi.org/10.1016/S00380717(02)00251-1, 2003.

Fierer, N., Jackson, J. A., Vilgalys, R., and Jackson, R. B.: Assessment of soil microbial community structure by use of taxonspecific quantitative PCR assays, Appl. Environ. Microb., 71, 4117-4120, https://doi.org/10.1128/AEM.71.7.4117-4120.2005, 2005.

Fierer, N., Bradford, M. A., and Jackson, R. B.: Toward an ecological classification of soil bacteria, Ecology, 88, 1354-1364, https://doi.org/10.1890/05-1839, 2007. 
Fierer, N., Lauber, C. L., Ramirez, K. S., Zaneveld, J., Bradford, M. A., and Knight, R.: Comparative metagenomic, phylogenetic and physiological analyses of soil microbial communities across nitrogen gradients, ISME J., 6, 1007-1017, https://doi.org/10.1038/ismej.2011.159, 2012.

Foesel, B. U., Rohde, M., and Overmann, J.: Blastocatella fastidiosa gen. nov., sp. nov., isolated from semiarid savanna soil-the first described species of Acidobacteria subdivision 4, Syst. Appl. Microbiol., 36, 82-89, https://doi.org/10.1016/j.syapm.2012.11.002, 2013.

Gao, Q., Ma, L., Fang, Y., Zhang, A., Li, G., Wang, J., $\mathrm{Wu}, \mathrm{D} ., \mathrm{Wu}, \mathrm{W}$, and $\mathrm{Du}, \mathrm{Z}$. : Conservation tillage for 17 years alters the molecular composition of organic matter in soil profile, Sci. Total Environ., 762, 143116, https://doi.org/10.1016/j.scitotenv.2020.143116, 2021.

Garcia-Fraile, P., Benada, O., Cajthaml, T., Baldrian, P., and Llado, S.: Terracidiphilus gabretensis gen. nov., sp nov., an abundant and active forest soil Acidobacteria important in organic matter transformation, Appl. Environ. Microbiol., 82, 560-569, https://doi.org/10.1128/AEM.03353-15, 2016.

Giller, K. E., Witter, E., Corbeels, M., and Tittonell, P.: Conservation agriculture and smallholder farming in Africa: The heretics' view, Field Crop. Res., 114, 23-34, https://doi.org/10.1016/j.fcr.2009.06.017, 2009.

Guo, J. H., Liu, X. J., Zhang, Y., Shen, J. L., Han, W. X., Zhang, W. F., Christie, P., Goulding, K. W. T., Vitousek, P. M., and Zhang, F. S.: Significant acidification in major Chinese croplands, Science, 327, 1008-1010, https://doi.org/10.1126/science.1182570, 2010.

Hamamura, N., Olson, S. H., Ward, D. M., and Inskeep, W. P.: Microbial population dynamics associated with crude-oil biodegradation in diverse soils, Appl. Environ. Microb., 72, 6316-6324, https://doi.org/10.1128/AEM.01015-06, 2006.

Hao, M., Hu, H., Liu, Z., Dong, Q., Sun, K., Feng, Y., Li, G., and Ning, T.: Shifts in microbial community and carbon sequestration in farmland soil under long-term conservation tillage and straw returning, Appl. Soil Ecol., 136, 43-54, https://doi.org/10.1016/j.apsoil.2018.12.016, 2019.

Hobara, S., Osono, T., Hirose, D., Noro, K., Hirota, M., and Benner, R.: The roles of microorganisms in litter decomposition and soil formation, Biogeochemistry, 118, 471-486, https://doi.org/10.1007/s10533-014-9956-3, 2014.

Hou, D., Bolan, N. S., Tsang, D. C. W., Kirkham, M. B., and O'Connor, D.: Sustainable soil use and management: an interdisciplinary and systematic approach, Sci. Total Environ., 729, 138961, https://doi.org/10.1016/j.scitotenv.2020.138961, 2020.

Hu, X., Liu, J., Liang, A., Li, L., Yao, Q., Yu, Z., Li, Y., Jin, J., Liu, X., and Wang, G.: Conventional and conservation tillage practices affect soil microbial co-occurrence patterns and are associated with crop yields, Agr. Ecosyst. Environ., 319, 107534, https://doi.org/10.1016/j.agee.2021.107534, 2021.

Huang, R., Wang, Y., Liu, J., Li, J., Xu, G., Luo, M., Xu, C., Ci, E., and Gao, M.: Variation in $\mathrm{N}_{2} \mathrm{O}$ emission and $\mathrm{N}_{2} \mathrm{O}$ related microbial functional genes in straw- and biocharamended and non-amended soils, Appl. Soil Ecol., 137, 57-68, https://doi.org/10.1016/j.apsoil.2019.01.010, 2019.

Jena, P. R.: Can minimum tillage enhance productivity? Evidence from smallholder farmers in Kenya, J. Clean.Prod., 218, 465475, https://doi.org/10.1016/j.jclepro.2019.01.278, 2019.
Ji, Y., Liu, P., and Conrad, R.: Response of fermenting bacterial and methanogenic archaeal communities in paddy soil to progressing rice straw degradation, Soil Biol. Biochem., 124, 70-80, https://doi.org/10.1016/j.soilbio.2018.05.029, 2018.

Jin, J.: Effects of different management practices on the soilwater balance and crop yield for improved dryland farming in the Chinese Loess Plateau, Soil Till. Res., 96, 131-144, https://doi.org/10.1016/j.still.2007.05.002, 2007.

Joa, J. H., Weon, H. Y., Hyun, H. N., Jeun, Y. C., and Koh, S. W.: Effect of long-term different fertilization on bacterial community structures and diversity in citrus orchard soil of volcanic ash, J. Microbiol., 52, 995-1001, https://doi.org/10.1007/s12275-0144129-6, 2014.

Karthikeyan, L., Chawla, I., and Mishra, A. K.: A review of remote sensing applications in agriculture for food security: Crop growth and yield, irrigation, and crop losses, J. Hydrol., 586, 124905, https://doi.org/10.1016/j.jhydrol.2020.124905, 2020.

Kassam, A., Li, H., Niino, Y., Friedrich, T., Jin, H., and Wang, X.: Current status, prospect and policy and institutional support for Conservation Agriculture in the Asia-Pacific region, Int. J. Agric. Biol. Eng., 7, 1-13, https://doi.org/10.3965/j.ijabe.20140705.001, 2014.

Kopittke, P. M., Menzies, N. W., Wang, P., McKenna, B. A., and Lombi, E.: Soil and the intensification of agriculture for global food security, Environ. Int., 132, 105078, https://doi.org/10.1016/j.envint.2019.105078, 2019.

Li, C., Yan, K., Tang, L., Jia, Z., and Li, Y.: Change in deep soil microbial communities due to longterm fertilization, Soil Biol. Biochem., 75, 264-272, https://doi.org/10.1016/j.soilbio.2014.04.023, 2014.

Li, Q., Li, A., Dai, T., Fan, Z., Luo, Y., Li, S., Yuan, D., Zhao, B., Tao, Q., Wang, C., Li, B., Gao, X., Li, Y., Li, H., and Wilson, J. P.: Depth-dependent soil organic carbon dynamics of croplands across the Chengdu Plain of China from the 1980s to the 2010s, Glob. Change Biol., 26, 4134-4146, https://doi.org/10.1111/gcb.15110, 2020.

Li, S., Zhang, S., Pu, Y., Li, T., Xu, X., Jia, Y., Deng, O., and Gong, G.: Dynamics of soil labile organic carbon fractions and C-cycle enzyme activities under straw mulch in Chengdu Plain, Soil Till. Res., 155, 289-297, https://doi.org/10.1016/j.still.2015.07.019, 2016.

Li, X., Sun, J., Wang, H., Li, X., Wang, J., and Zhang, H.: Changes in the soil microbial phospholipid fatty acid profile with depth in three soil types of paddy fields in China, Geoderma, 290, 69-74, https://doi.org/10.1016/j.geoderma.2016.11.006, 2017.

Liang, B., Ma, C., Fan, L., Wang, Y., and Yuan, Y.: Soil amendment alters soil physicochemical properties and bacterial community structure of a replanted apple orchard, Microbiol. Res., 216, 111, https://doi.org/10.1016/j.micres.2018.07.010, 2018.

Ling, N., Chen, D., Guo, H., Wei, J., Bai, Y., Shen, Q., and Hu, S.: Differential responses of soil bacterial communities to long-term $\mathrm{N}$ and $\mathrm{P}$ inputs in a semi-arid steppe, Geoderma, 292, 25-33, https://doi.org/10.1016/j.geoderma.2017.01.013, 2017.

Liu, Q., Liu, G., Huang, C., and Li, H.: Soil physicochemical properties associated with quasi-circular vegetation patches in the Yellow River Delta, China, Geoderma, 337, 202-214, https://doi.org/10.1016/j.geoderma.2018.09.021, 2019. 
Lu, R. (Eds): Methods of soil and agro-chemistry analysis, China Agricultural Science and Technology Press, Beijing, China, 2000 (in Chinese).

Lupwayi, N. Z., Lafond, G. P., Ziadi, N., and Grant, C. A.: Soil microbial response to nitrogen fertilizer and tillage in barley and corn, Soil Till. Res., 118, 139-146, https://doi.org/10.1016/j.still.2011.11.006, 2012.

Maarastawi, S. A., Frindte, K., Geer, R., Kröber, E., and Knief, C.: Temporal dynamics and compartment specific rice straw degradation in bulk soil and the rhizosphere of maize, Soil Biol. Biochem., 127, 200-212, https://doi.org/10.1016/j.soilbio.2018.09.028, 2018.

Magoc, T. and Salzberg, S. L.: FLASH: fast length adjustment of short reads to improve genome assemblies, Bioinformatics, 27, 2957-2963, https://doi.org/10.1093/bioinformatics/btr507, 2011.

Menéndez-Serra, M., Triadó-Margarit, X., Castañeda, C., Herrero, J., and Casamayor, E. O.: Microbial composition, potential functional roles and genetic novelty in gypsum-rich and hypersaline soils of Monegros and Gallocanta (Spain), Sci. Total Environ., 650, 343-353, https://doi.org/10.1016/j.scitotenv.2018.09.050, 2019.

Nan, Q., Wang, C., Wang, H., Yi, Q., Liang, B., Xu, J., and $\mathrm{Wu}, \mathrm{W} .:$ Biochar drives microbially-mediated rice production by increasing soil carbon, J. Hazard. Mater., 387, 121680, https://doi.org/10.1016/j.jhazmat.2019.121680, 2020.

Nie, Y., Wang, M., Zhang, W., Ni, Z., Hashidoko, Y., and Shen, W.: Ammonium nitrogen content is a dominant predictor of bacterial community composition in an acidic forest soil with exogenous nitrogen enrichment, Sci. Total Environ., 624, 407-415, https://doi.org/10.1016/j.scitotenv.2017.12.142, 2018.

Palm, C., Blanco-Canqui, H., Declerck, F., Gatere, L., and Grace, P.: Conservation agriculture and ecosystem services: An overview, Agr. Ecosyst. Environ., 187, 87-105, https://doi.org/10.1016/j.agee.2013.10.010, 2014.

Parks, D. H., Tyson, G. W., Hugenholtz, P., and Beiko, R. G.: STAMP: statistical analysis of taxonomic and functional profiles, Bioinformatics, 30, 3123-3124, https://doi.org/10.1093/bioinformatics/btu494, 2014.

Pastorelli, R., Vignozzi, N., Landi, S., Piccolo, R., Orsini, R., Seddaiu, G., Roggero, P. P., and Pagliai, M.: Consequences on macroporosity and bacterial diversity of adopting a no-tillage farming system in a clayish soil of Central Italy, Soil Biol. Biochem., 66, 78-93, https://doi.org/10.1016/j.soilbio.2013.06.015, 2013.

Peng, X. and Wang, W.: Stoichiometry of soil extracellular enzyme activity along a climatic transect in temperate grasslands of northern China, Soil Biol. Biochem., 98, 74-84, https://doi.org/10.1016/j.soilbio.2016.04.008, 2016.

Pittelkow, C. M., Liang, X., Linquist, B. A., van Groenigen, K. J., Lee, J., Lund, M. E., Gestel, N., Six, J., Venterea, R. T., and van Kessel, C.: Productivity limits and potentials of the principles of conservation agriculture, Nature, 517, 368-368, https://doi.org/10.1038/nature13809, 2015.

Qiu, Y., Lv, W., Wang, X., Xie, Z., and Wang, Y.: Long-term effects of gravel mulching and straw mulching on soil physicochemical properties and bacterial and fungal community composition in the Loess Plateau of China, Eur. J. Soil Biol., 98, 103188, https://doi.org/10.1016/j.ejsobi.2020.103188, 2020.
Quast, C., Pruesse, E., Yilmaz, P., Gerken, J., Schweer, T. Yarza, P., Peplies, J., and Glockner, F. O.: The SILVA ribosomal RNA gene database project: improved data processing and web-based tools, Nucleic Acids Res., 41, D590-D596, https://doi.org/10.1093/nar/gks1219, 2013.

Schreiter, S., Ding, G., Heuer, H., Neumann, G., Sandmann, M., Grosch, R., Kropf, S., and Smalla, K.: Effects of the soil type on the microbiome in the rhizosphere of field-grown lettuce, Front. Microbiol., 5, 144, https://doi.org/10.3389/fmicb.2014.00144, 2014.

Segal, L. M., Miller, D. N., Mcghee, R. P., Loecke, T. D., Cook, K. L., and Shapiro, C. A.: Bacterial and archaeal ammonia oxidizers respond differently to long-term tillage and fertilizer management at a continuous maize site, Soil Till. Res., 168, 110-117, https://doi.org/10.1016/j.still.2016.12.014, 2017.

Shang, Q., Yang, X., Gao, C., Wu, P., Liu, J., Xu, Y., Shen, Q., Zou, J., and Guo, S.: Net annual global warming potential and greenhouse gas intensity in Chinese double rice-cropping systems: a 3year field measurement in long-term fertilizer experiments, Glob. Change Biol., 17, 2196-2210, https://doi.org/10.1111/j.13652486.2010.02374.x, 2011.

Singh, U., Choudhary, A. K., and Sharma, S.: Comparative performance of conservation agriculture vis-a-vis organic and conventional farming, in enhancing plant attributes and rhizospheric bacterial diversity in Cajanus cajan: A field study, Eur. J. Soil Biol., 99, 103197, https://doi.org/10.1016/j.ejsobi.2020.103197, 2020.

Song, Y., Liu, C., Wang, X., Ma, X., Jiang, L., Zhu, J., Gao, J., and Song, C.: Microbial abundance as an indicator of soil carbon and nitrogen nutrient in permafrost peatlands, Ecol. Indic., 115, 106362, https://doi.org/10.1016/j.ecolind.2020.106362, 2020.

Stowe, D. C., Lamhamedi, M. S., Carles, S., Fecteau, B., Margolis, H. A., Renaud, M., and Bernier, P. Y.: Managing irrigation to reduce nutrient leaching in containerized white spruce seedling production, New Forest, 40, 185-204, https://doi.org/10.1007/s11056-010-9193-0, 2010.

Sun, R., Zhang, X., Guo, X., Wang, D., and Chu, H.: Bacterial diversity in soils subjected to long-term chemical fertilization can be more stably maintained with the addition of livestock manure than wheat straw, Soil Biol. Biochem., 88, 9-18, https://doi.org/10.1016/j.soilbio.2015.05.007, 2015.

Tellez-Rio, A., García-Marco, S., Navas, M., López-Solanilla, E., Tenorio, J. L., and Vallejo, A.: $\mathrm{N}_{2} \mathrm{O}$ and $\mathrm{CH}_{4}$ emissions from a fallow-wheat rotation with low $\mathrm{N}$ input in conservation and conventional tillage under a Mediterranean agroecosystem, Sci. Total Environ., 1, 85-94, https://doi.org/10.1016/j.scitotenv.2014.11.041, 2015.

Thompson, L. R., Sanders, J. G., McDonald, D., Amir, A., Ladau, J., and Locey, K. J.: A communal catalogue reveals earth's multiscale microbial diversity, Nature, 551, 457-463, https://doi.org/10.1038/nature24621, 2017.

van Leeuwen, J. P., Djukic, I., Bloem, J., Lehtinen, T., Hemerik, L., de Ruiter, P. C., and Lair, G. J.: Effects of land use on soil microbial biomass, activity and community structure at different soil depths in the Danube floodplain, Eur. J. Soil Biol., 79, 14-20, https://doi.org/10.1016/j.ejsobi.2017.02.001, 2017.

Wagg, C., Bender, S. F., Widmer, F., and van der Heijden, M. G. A.: Soil biodiversity and soil community composition deter- 
mine ecosystem multifunctionality, P. Natl. Acad. Sci. USA, 111, 5266-5270, https://doi.org/10.1073/pnas.1320054111, 2014.

Wang, D., Li, T., Huang, K., He, X., and Zhang, X.: Roles and correlations of functional bacteria and genes in the start-up of simultaneous anammox and denitrification system for enhanced nitrogen removal, Sci. Total Environ., 655, 1355-1363, https://doi.org/10.1016/j.scitotenv.2018.11.321, 2019a.

Wang, H., Guo, Q., Li, X., Li, X., Yu, Z., Li, X., Yang, T., Su, Z., Zhang, H., and Zhang, C.: Effects of longterm no-tillage with different straw mulching frequencies on soil microbial community and the abundances of two soil-borne pathogens, Appl. Soil Ecol., 148, 103488, https://doi.org/10.1016/j.apsoil.2019.103488, 2020.

Wang, J., Wang, D., Zhang, G., and Wang, C.: Effect of wheat straw application on ammonia volatilization from urea applied to a paddy field, Nutr. Cycl. Agroecosys., 94, 73-84, https://doi.org/10.1007/s10705-012-9527-8, 2012.

Wang, L., Yuan, X., Liu, C., Li, Z., Chen, F., Li, S., Wu, L., and Liu, Y.: Soil $\mathrm{C}$ and $\mathrm{N}$ dynamics and hydrological processes in a maize-wheat rotation field subjected to different tillage and straw management practices, Agr. Ecosyst. Environ., 285, 106616, https://doi.org/10.1016/j.agee.2019.106616, 2019.

Wang, W., Akhtar, K., Ren, G., Yang, G., Feng, Y., and Yuan, L.: Impact of straw management on seasonal soil carbon dioxide emissions, soil water content, and temperature in a semi-arid region of China, Sci. Total Environ., 652, 1-482, https://doi.org/10.1016/j.scitotenv.2018.10.207, 2019.

Wegner, C. E. and Liesack, W.: Microbial community dynamics during the early stages of plant polymer breakdown in paddy soil, Environ. Microbiol., 18, 2825-2842, https://doi.org/10.1111/1462-2920.12815, 2016.

Wolff, D., Krah, D., Dötsch, A., Ghattas, A. K., Wick, A., and Ternes, T. A.: Insights into the variability of microbial community composition and micropollutant degradation in diverse biological wastewater treatment systems, Water Res., 143, 313-324, https://doi.org/10.1016/j.watres.2018.06.033, 2018.

Xu, S., Hou, P., Xue, L., Wang, S., and Yang, L.: Treated domestic sewage irrigation significantly decreased the $\mathrm{CH}_{4}, \quad \mathrm{~N}_{2} \mathrm{O}$ and $\mathrm{NH}_{3}$ emissions from paddy fields with straw incorporation, Atmos. Environ., 169, 1-10, https://doi.org/10.1016/j.atmosenv.2017.09.009, 2017.

Ye, J., Joseph, S. D., Ji, M., Nielsen, S., Mitchell, D. R. G., Donne, S., Horvat, J., Wang, J., Munroe, P., and Thomas, T.: Chemolithotrophic processes in the bacterial communities on the surface of mineral-enriched biochars, ISME J., 11, 1087-1011, https://doi.org/10.1038/ismej.2016.187, 2017.
Yu, H., Ling, N., Wang, T., Zhu, C., Wang, Y., Wang, S., and Gao, Q.: Responses of soil biological traits and bacterial communities to nitrogen fertilization mediate maize yields across three soil types, Soil Till. Res., 185, 61-69, https://doi.org/10.1016/j.still.2018.08.017, 2019.

Zhang, D., Ji, X., Meng, Z., Qi, W., and Qiao, K.: Effects of fumigation with 1,3-dichloropropene on soil enzyme activities and microbial communities in continuouscropping soil, Ecotox. Environ. Safe, 169, 730-736, https://doi.org/10.1016/j.ecoenv.2018.11.071, 2019.

Zhang, P., Chen, X., Wei, T., Yang, Z., Jia, Z., Yang, B., Han, Q., and Ren, X.: Effects of straw incorporation on the soil nutrient contents, enzyme activities, and crop yield in a semiarid region of China, Soil Till. Res., 160, 65-72, https://doi.org/10.1016/j.still.2016.02.006, 2016.

Zhao, C., Song, Z. L., Zhuang, D. H., Wang, J., Xie, S., and Liu, G. B.: Urea fertilization decreases soil bacterial diversity, but improves microbial biomass, respiration, and N-cycling potential in a semiarid grassland, Biol. Fert. Soils, 55, 229-242, https://doi.org/10.1007/s00374-019-01344-z, 2019.

Zhao, Y., Wang, M., Hu, S., Zhang, X., Ouyang, Z., Zhang, G., Huang, B., Zhao, S., Wu, J., Xie, D., Zhu, B., Yu, D., Pan, X., Xu, S., and Shi, X.: Economics- and policy-driven organic carbon input enhancement dominates soil organic carbon accumulation in Chinese croplands, P. Natl. Acad. Sci. USA, 115, 4045-4050, https://doi.org/10.1073/pnas.1700292114, 2018.

Zhou, Z., Shen, Y., Du, C., Zhou, J., Qin, Y., and Wu, Y.: Economic and soil environmental benefits of using controlled-release bulk blending urea in the North China Plain, Land Degrad. Dev., 28, 2370-2379, https://doi.org/10.1002/ldr.2767, 2017.

Zhou, Z., Chen, K., Yu, H., Chen, Q., Wu, F., Zeng, X., Tu, S., Qin, Y., Meakin, R., and Fan, X.: Changes in tea performance and soil properties after three years of polyhalite application, Agron. J., 111, 1967-1976, https://doi.org/10.2134/agronj2018.06.0393, 2019a.

Zhou, Z., Zeng, X., Chen, K., Li, Z., Guo, S., Shangguan, Y., Tu, S., and Qin, Y.: Long-term straw mulch effects on crop yields and soil organic carbon fractions at different depths under a no-till system on the Chengdu Plain, China, J. Soil. Sediment., 19, 2143-2152, https://doi.org/10.1007/s11368-01802234-x, 2019b. 